\title{
Shallow landslide prediction and analysis with risk assessment using a spatial model in a coastal region in the state of São Paulo, Brazil
}

\author{
P. I. M. Camarinha ${ }^{1}$, V. Canavesi ${ }^{1}$, and R. C. S. Alvalá ${ }^{2}$ \\ ${ }^{1}$ National Institute for Space Research, São José dos Campos, Brazil \\ ${ }^{2}$ Brazilian Center for Monitoring and Warnings of Natural Disasters - CEMADEN, Cachoeira Paulista, Brazil \\ Correspondence to: P. I. M. Camarinha (pedro.camarinha@inpe.br)
}

Received: 21 August 2013 - Published in Nat. Hazards Earth Syst. Sci. Discuss.: 1 October 2013

Revised: 10 August 2014 - Accepted: 27 August 2014 - Published: 17 September 2014

\begin{abstract}
This study presents a methodology for susceptibility mapping of shallow landslides just from data and software from the public domain. The study was conducted in a mountainous region located on the southeastern Brazilian coast, in the state of São Paulo. The proposal is that the methodology can be replicated in a practical and reliable way in several other municipalities that do not have such mappings and that often suffer from landslide-related disasters. The susceptibility mapping was generated based on the following maps: geological, soils, slope, horizontal and vertical curvatures, and land use. The thematic classes of these maps were weighted according to technical and scientific criteria related to the triggering of landslides, and were crossed by the fuzzy gamma technique. The mapping was compared with the risk sector survey made by the Brazilian Geological Survey (CPRM), which is the official database used by municipalities and civil defense in risk management. The results showed positive correlations, so that the critical risk sectors had higher proportions for the more susceptible classes. To compare the approach with other studies using landslide-scar maps, correlated indices were evaluated, which also showed satisfactory results, thus indicating that the methodology presented is appropriate for risk assessment in urban areas.
\end{abstract}

\section{Introduction}

In Brazil, there were around 150 records of natural disasters during the period 1900-2013, whose associated numbers are also alarming: 10052 fatalities, 71 million people affected and a loss of about USD 16 billion (EM-DAT, 2013). Floods were the most frequent event (57\% of the total), followed by mass movements $(11 \%)$. Most of the disasters in Brazil (over $80 \%$ ) are associated with severe atmospheric instability, which is responsible for triggering floods, wind storms, tornadoes, hail and landslides.

The number and frequency of natural disasters have increased in recent decades, and are due mainly to a combination of factors: population growth, socio-spatial segregation, accumulation capital in dangerous areas, and global changes (Winchester and Szalachman, 2009). Such factors have assumed that the developing countries and the poorest are those that accumulate the highest number of fatal casualties and disasters, the dangerous areas (hazard zones) being focused in cities in port areas and river plains (Anbalagan, 1992; Kobiyama et al., 2006; Marcelino et al., 2006).

Countries with a high population density on the coast followed by mountain ranges are usually very affected by the combination of extreme rain events that could lead to landslide-related disasters. Thus, several studies had focused on evaluating the causes and mechanisms of inducing mass movements on the slopes and aiming to identify where they can occur, generally based on a set of environmental characteristics (Varnes et al., 1984; Aleotti and Chowdhury, 1999; Carrara et al., 1995; Guzzetti et al., 2005; Chung and Fabbri, 2005).

However, mapping and prediction of landslide probability or its potential is not a simple task, because it depends on very complex knowledge of mass movements on the slopes as well as all the factors that control them. The reliability of landslide susceptibility maps depends mainly on the quantity 

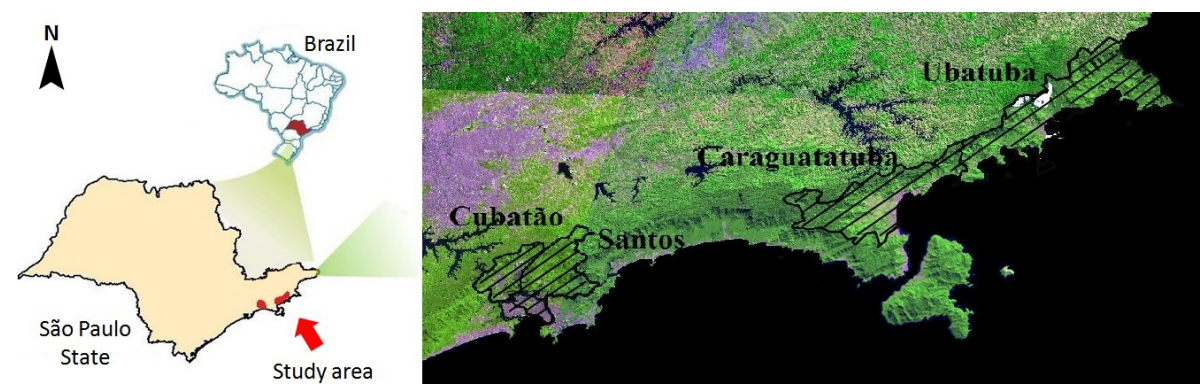

Figure 1. Study area in São Paulo State, Brazil. On the right, the image is a color composition (RGB 453) of Resourcesat/LISS III.

and quality of the available data, the scale of the work and the selection of the appropriate methodology of analysis and modeling (Ayalew and Yamagishi, 2005). Among the different methodological approaches related to the subject, it is common to include environmental factors, triggering factors, and historic landslide occurrences (Sassa et al., 2004; van Westen et al., 2006). The problem is that these data are not always available for many places or cities, as is the case for most municipalities in Brazil. In such cases, the lack of data is associated with the difficulty in obtaining information for a country of continental dimensions, which requires several teams of experts and, consequently, resources for feasibility. Moreover, in Brazil, there is no tradition of obtaining this type of survey, since only recently have landslide-related disasters become more evident to society as a social, political and economic problem. In this way, few Brazilian cities have urban planning that takes into account this kind of threat. Thus, due to the increasing number of landslide-related disasters in the last decades in Brazilian cities, especially in the southeastern and southern regions of the country, recently the CPRM (Research and Mineral Resources Company) was tasked with a great mission to be fulfilled in the coming years: landslide risk mapping of urban areas in 821 municipalities and susceptibility mapping for the 286 municipalities considered critical. The purposes of the studies involving landslide prediction and assessments are to support and promote public policies that use such information on disaster mitigation, essentially exposing the main causal factors in relation to possible anthropogenic interference, also for the development of the phenomenon.

One of the critical regions of Brazil that requires disaster risk assessments involving landslides is the coastal plain in the state of São Paulo, near Serra do Mar, which is a mountain chain more than $1000 \mathrm{~m}$ above sea level. Such geophysical characteristics, followed by the great population growth, lack of urban planning and property speculation are some determinant factors of landslide-related disaster occurrence. This region is an important tourist center and has one of the biggest ports of the country, in addition to experiencing frequent natural disasters during the summer rains. The objective of this study was thus to evaluate the landslide susceptibility (specifically for shallow landslides) and land- slide risk in four coastal municipalities in the state of São Paulo, based on a methodology by using a free geographic information system (GIS) and a free database aiming for landslide susceptibility mapping, which can provide a useful and reliable tool for natural disaster management. Due to the high demand of Brazilian municipalities that need landslide risk and susceptibility mapping, the aim is also to compare the results with the official data from CPRM, so that this methodology can be replicated in cities where no mapping exists.

\section{Study area}

The system represented by the mountains of Serra do Mar is the most prominent feature of the orographic Atlantic edge on the South American continent. Serra do Mar is a set of festooned cliffs of around $1000 \mathrm{~km}$ in length that runs from the state of Rio de Janeiro, in southern Brazil, to the state of Santa Catarina, to the south.

The area that will be studied in this work refers to a part of the São Paulo coast, composed of four municipalities: Santos, Ubatuba, Cubatão and Caraguatatuba (Fig. 1). In this region, Serra do Mar is imposed as a typical border of the plateau, often leveled by the top at altitudes from 800 to $1200 \mathrm{~m}$. In areas with more rugged terrain, the region is largely preserved by natural vegetation (Atlantic forest). On the other hand, the flatter coastal areas are highly modified and, with the passage of time, human activities have advanced towards the slopes (mainly urbanization processes). This region has a strategic importance for the economic development of the country, including ports, roads, pipelines, and relevant tourist centers. In addition to these important aspects, the region was chosen because it is frequently hit by extreme precipitation events that trigger landslides. As the changes in the landscape became more intense due to local development, risk exposure situations were also created for the population and its activities. Thus, these municipalities have historical records of natural disasters involving landslides since the early 20th century (Almeida and Carneiro, 1998). The main processes of mass movement that present a risk to society in this region are natural shallow landslides or, 
Table 1. Demographic and geographic characteristics of the four municipalities evaluated.

\begin{tabular}{|c|c|c|c|c|c|c|c|c|}
\hline \multirow[t]{2}{*}{ Municipality } & \multirow{2}{*}{$\begin{array}{l}\text { Area } \\
\left(\mathrm{km}^{2}\right)\end{array}$} & \multicolumn{5}{|c|}{ Population (census 2009) } & \multirow{2}{*}{$\begin{array}{r}\text { Demographic density } \\
\left(\text { pop. } \mathrm{km}^{-2} \text { ) }\right.\end{array}$} & \multirow[t]{2}{*}{ HDI-M } \\
\hline & & Total & $\begin{array}{r}\text { Urban } \\
\text { zone } \\
\text { (pop.) }\end{array}$ & $\%$ & $\begin{array}{r}\text { Rural } \\
\text { zone } \\
\text { (pop.) }\end{array}$ & $\%$ & & \\
\hline Santos & 280.30 & 419400 & 419086 & 99.93 & 314 & 0.07 & 1496.26 & 0.840 \\
\hline Cubatão & 142.28 & 108309 & 107661 & 99.40 & 648 & 0.60 & 761.23 & 0.772 \\
\hline Caraguatatuba & 483.95 & 100899 & 97449 & 96.58 & 3450 & 3.42 & 208.49 & 0.802 \\
\hline Ubatuba & 723.82 & 78870 & 76958 & 95.58 & 1912 & 2.42 & 108.96 & 0.751 \\
\hline
\end{tabular}

as observed more frequently, the induced shallow landslides in cut-and-fill slopes, both generally associated with shallow soils and colluvial deposits (Wolle and Carvalho, 1989; IPT, 1986; Tatizana et al., 1987a). The earliest recorded case of a landslide-related disaster was in the municipality of Santos on 10 March 1928. Landslides occurred in large parts of the slopes of Mont Serrat, which buried many homes and several outbuildings of a great hospital, and which resulted in 80 deaths.

Table 1 characterizes the four municipalities evaluated in this study. They occupy an area of approximately $1600 \mathrm{~km}^{2}$. Santos and Caraguatatuba stand out in the HDIM (Municipal Human Development Index), and are considered "very high", and Cubatão and Ubatuba were classified by the HDI-M as "high", reaffirming the importance of these municipalities in Brazil.

Throughout every rainy season (November-April) in the studied region, generally there are isolated occurrences of shallow landslides. However, the extreme meteorological events that trigger the more catastrophic landslides usually occur between January and mid-March.

According to IPMet (2013), these municipalities have 21 registers of landslide-related events, with 2182 victims (homeless and displaced persons) and 12 deaths in the last 20 years (1993-2013), as shown in Table 2. However, there are still records of great landslide disasters before this period, and this must be highlighted. For example, in the municipality of Santos, on 10 March 1928, there were landslides in large parts of the slopes of Mont Serrat, which buried many homes and several outbuildings of the Holy House of Mercy, and which resulted in 80 deaths (Instituto Geológico, 2009); in 1946, there were 56 deaths, and on 24 March 1990, there were 2 fatal casualties and 174 homeless persons. In the city of Cubatão on 6 February 1994, the Presidente Bernardes oil refinery was partially buried by debris flow without victims, but with damages of USD 44 million (Cruz et al., 2000; Massad et al., 2004). In the municipality of Caraguatatuba, on 18 March 1967, the city was the target of an extreme rainfall event $(576 \mathrm{~mm}$ in $48 \mathrm{~h}$ ) that triggered a hundred landslides, with 120 people killed and 400 houses destroyed (Kanji et al., 2008). It may be interesting to analyze the results of the proposed
Table 2. Summary of landslide disasters on the coast of Sao Paulo, Brazil (last 20 years) in the IPMet (2013) database.

\begin{tabular}{lllc}
\hline Local & Date & Affected & Killed \\
\hline Santos & 1 Jan 2000 & 20 homeless & - \\
& 6 Sep 2009 & 20 homeless and 1 displaced & - \\
& 1 Jan 2011 & 8 homeless and 52 displaced & - \\
12 Apr 2011 & & 2 \\
Cubatão & 11 Dec 2004 & 3 injured & - \\
& 24 Feb 2010 & 34 homeless & - \\
& 25 Oct 2010 & 34 homeless and 160 displaced & - \\
& 31 Dec 2010 & 5 displaced & - \\
& 28 Feb 2011 & 9 homeless & - \\
15 Dec 2011 & 8 displaced & 7 \\
Ubatuba & 10 Jan 2013 & 67 displaced & 1 \\
& 22 Feb 2013 & 500 homeless & 1 \\
& 13 Feb 1996 & 226 homeless and 2 injured & 1 \\
& 29 Nov 2013 & 3 injured & - \\
& 17 Nov 2008 & 34 homeless & - \\
& 4 Feb 2009 & 30 homeless and 137 displaced & - \\
& 20 Apr 2009 & 20 homeless and 27 displaced & - \\
31 Dec 2009 & 38 homeless and 500 displaced & - \\
15 Jan 2010 & 5 displaced & 180 homeless and 55 displaced & - \\
& 23 Dec 2011 & 4 displaced & \\
17 Dec 2009 & & & - \\
& & & \\
& & &
\end{tabular}

methodology in those areas where the disasters occurred. However, there are no geo-referenced records or paper maps of such events, making it impossible to identify them today.

During the second half of the last century, the regular areas that relied on the local infrastructure were practically exhausted due to the great population growth and property speculation. These cities has some legal restrictions about the verticalization process, which has led the urban sprawl migrated toward areas close to the slopes and hills (Fig. 2), which is a factor that increases the probability of landsliderelated disasters in these areas.

\section{Methodology}

In order to promote a complete understanding of the methodology, some important terms that are used throughout the study are defined as follows: "theme" is a nomenclature adopted for the data represented in each used map (i.e., topographic, soil, geological, and land-use maps). "Class" is 


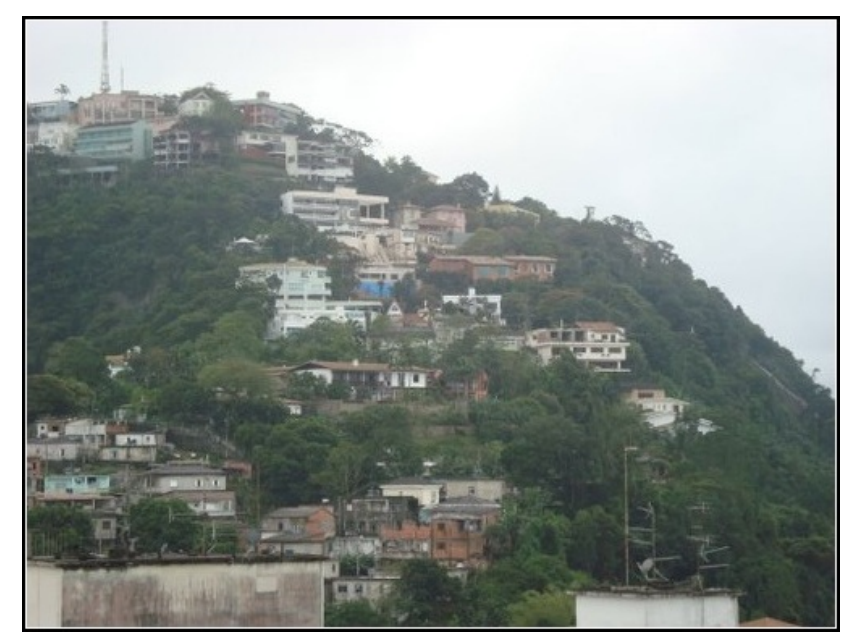

Figure 2. Picture illustrating irregular occupation of the slopes in Santos, SP, Brazil. Photo by J. C. de Carvalho.

associated with each division (category) of the themes (for example, for land maps, the "urban area" is a class, as is "forest" or "pasture" and so on). The "susceptibility class" is the hierarchy category of the final map of susceptibility obtained from the fuzzy gamma technique. "Sector risks" are the geographical boundaries of a site (represented by a polygon), where there are natural threats that expose the population to a risk. These sectors were analyzed and identified by the CPRM, and are considered a basis of urban planning and risk management, especially for civil defense. "Risk levels" are subdivisions of "sector risks", defined by CPRM as a hierarchical categorization of risk sectors regarding the probability of landslide occurrence and its potential impacts. Basically, it is related to an analysis that evaluates the predisposing geological and geotechnical conditions and the level of human intervention on each occupied slope, which takes into account such factors as the type of terrain, signs of soil movement (step abatement), cracks in houses, inclined poles or trees, erosion at the bases of slopes, length of slopes, and others. The classes range from R1 (less critical, low probability of occurrence) to R4 (most critical, high probability of occurrence).

The methodology was elaborated on by aiming for the generation of a susceptibility map of shallow landslides by using only spatial data and public domain software. The choice of shallow landslides is due to the fact that this is the main mechanism of slope instability in the study region (Serra do Mar).

Shallow landslides have flat surfaces of rupture, and they generally accompany mechanical and/or existing hydrological discontinuities within the material (soil), with very rapid displacement of mass (Hutchinson, 1986a, b; Fernandes and Amaral, 1996). Selby (1993) states that such surfaces have generally developed over a boundary between different soil densities or permeability materials. Guidicini and
Nieble (1984) reported that the sliding surface is usually a reflection of the geological structure of the land, and can consist of bedding planes, schistosity, gneissification, jointing, failures, stress-relieving joints, cracks filled by amendment material, and contacts between layers. Wolle and Carvalho (1994) characterize this type of movement to the Serra do Mar on the surface of a colluvium horizon and a saprolite horizon (residual soil), with thicknesses ranging from less than $1 \mathrm{~m}$ to a few meters, depending on the lithology, and the instability mechanisms are associated with conditions of water flow, soil strength and permeability profile. Based on all these statements, and as highlighted by Atkinson and Massari (1998), several factors may influence the shallow landslide susceptibility (enhancing or mitigating), such as the presence and type of vegetation and the land coverage, curvatures of the topography (vertical and horizontal), slope (declivity), soils and geology. These are thus the variables used in the methodology of susceptibility mapping and that are expressed by thematic maps. The crossing of this information (maps) and how these variables are related to the phenomena are given through the spatial inference technique of algebra maps known as fuzzy gamma.

The geological environment presents some peculiar characteristics that favor the triggering of shallow landslides. These characteristics are related to lithology, structure (fractures, stratification, joints, etc.), internal properties (texture and mineralogy), cohesion and angle of friction, permeability and weathering mantle. When the rock discontinuities are very close and concentrated, this could favor the weathering action, thereby facilitating the appearance of instability zones (Ritter et al., 1995; Augusto Filho and Virgili, 1998; Bigarella et al., 2007).

The topography, such as the angle of the slope, aspect and curvatures, presents as an important factor in the distribution and concentration of soil water. The topography, according to some authors, is a reflection of their lithologic environment that varies according to the active climate regime (Small, 1970; Pierson, 1980; Wilson and Dietrich, 1987; Gao, 1993; Ritter et al., 1995; Fernandes et al., 2004; Vieira and Fernandes, 2004; Bigarella et al., 2007). Among the topographic parameters, the curvature, specifically the concave shape (hollows), has received important attention. Such importance is revealed by hydrological control of the slopes, i.e., determined by the areas of surface and sub-surface flows of water. Due to the fact that the "hollows" are sometimes made by deposits of materials from their surroundings (nose and ridge), when accumulated it can generate discontinuities between the original material developed in situ and the deposited material, thus favoring heterogeneity in permeability. These differences of permeability may favor the generation of zones of saturation and induce shallow landslides (Small, 1970; Pierson, 1980: Wilson and Dietrich, 1987; Guimarães et al., 2003; Bogaart and Troch, 2006).

Soils or "alteration mantles" are responses to the conditions imposed by weathering agents (physical-chemical) in 


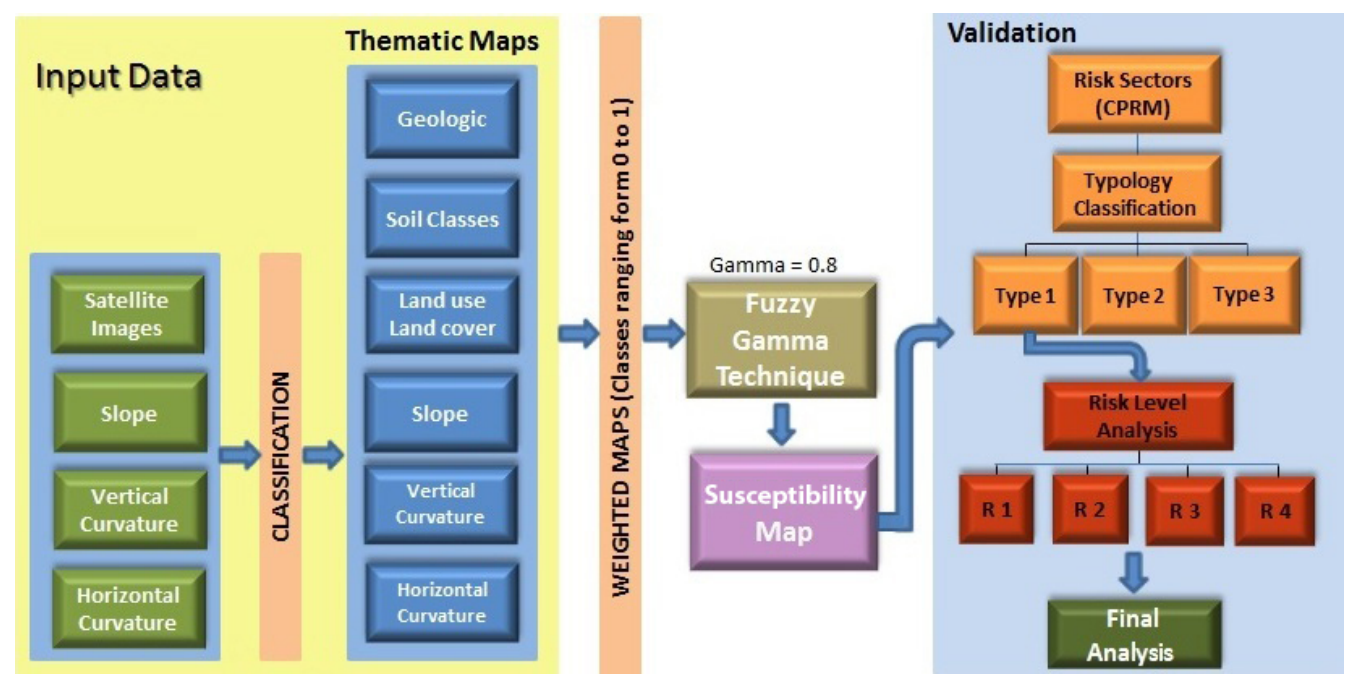

Figure 3. Data and the methodology flowchart.

the rock. They can be eluvium, which are soils formed by the decomposition of their own source material and/or colluvium and talus soils transported in past times by transport agents or the collective movement of materials (Mousinho and Bigarella, 1965). According to Augusto Filho and Virgili (1998), as a result of this process in tropical and subtropical environments, the alteration mantles have large coverage areas, and their generation provides a different resistance and different permeability profiles, among other characteristics that are associated with the mechanisms of disruptions. Areas with different resistance profiles provide uneven soil permeability, which influences the concentration or water percolation, then reflecting the hydraulic conductivity of the material (Pierson, 1980).

Regarding the land cover, the most important relationship of this variable with the triggering of shallow landslides is given by different interactions with the vegetation cover (mainly with the cycle of wetting-drying and infiltration process) and destabilizing agents due to human actions. Greenway (1987) explains the role of vegetation by two factors: the mechanical - that is the physical interaction of the foliage or root system with the slope; and hydrological - which are related with complex factors of the hydrologic cycle. Tatizana et al. (1987a) as Kuriakose (2006) point out the fundamental role of vegetation in the dynamic cycle of water on the slope and, consequently, on the ground. Both authors point to the role of canopy water retention, preventing direct impact on the soil as well as the retention of a portion of precipitated water, which returns to the atmosphere by evaporation, infiltration and reducing water runoff. Another important aspect of vegetation on hydrology is evapotranspiration. This factor decreases the saturation of the soil, providing better stability condition (Greenway, 1987).

Human activities may interfere with the stability of slopes by both inducing failure mechanisms as well as containing them. This will depend on the intervention degree of each location, the local infrastructure, the history of occupation, and on how this information can be represented by maps. In most cases, the definition of the thematic class of "urban area" on a map is just a type of land cover for such a location, but it generalizes the landslide triggering factors that may exist. Therefore, to evaluate the land use, it is important to have good local knowledge of the study area, so that one can assess the relationship between human actions and landslide conditioning factors that was not clear in the form of maps. Regarding the study region especially, the shallow landslides triggered are induced mainly in places where there are intense anthropogenic activities, especially in cut-and-fill slopes (for example, near on the banks of roads and irregular constructions on slopes). For this reason, the land-use map was also implemented, aiming to highlight the inducing factors that exist in urban areas that are expanding in steep relief.

Once the results are validated, the intention is that the methodology can be replicated in a practical way in other areas that require such mapping, not necessarily to the same type of mass movement analyzed. It is exactly for this reason that the fuzzy gamma technique and its respective step of weighting were used, because there is the flexibility to change the weights and variables involved, depending on the nature and characteristics of the phenomenon whose susceptibility one wants to map.

Basically, the methodology could be divided into four steps (Fig. 3): (i) survey and pre-processing of the spatial database required for landslide susceptibility analysis; (ii) preparation and formatting of spatial data to be used properly in the algebra map through the fuzzy gamma technique (thematic class weighting); (iii) generation of a landslide susceptibility map; and (iv) validation of the results. 

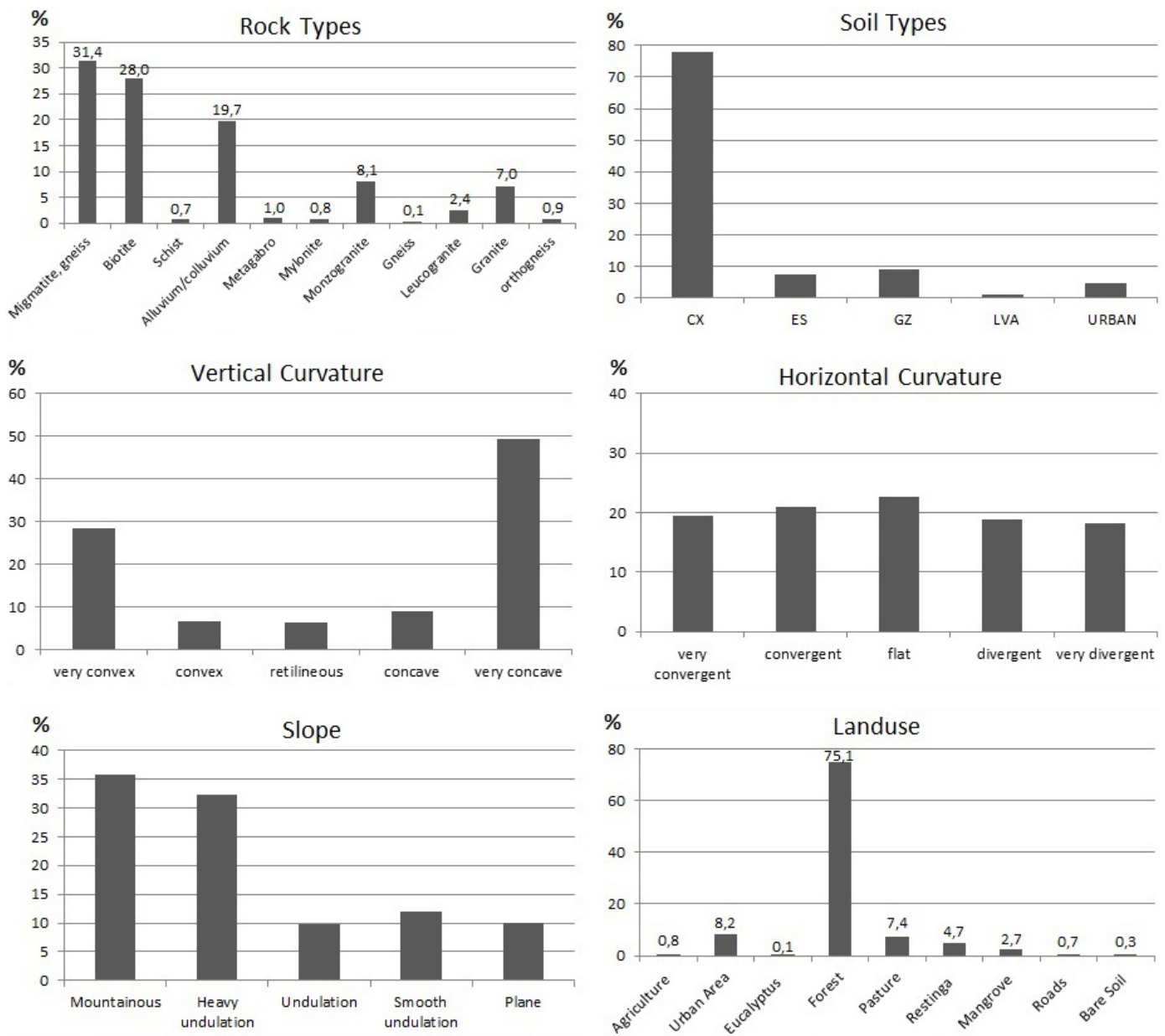

Figure 4. Histograms for the six themes considered in the study, with its class distributions.

\subsection{Survey and pre-processing of spatial database}

The maps surveys in this study include geology, soil, and topography, represented by the terrain slope, and horizontal and vertical curvature, and use map and land cover. These themes are related to the conditioning factors that trigger the landslide, which were explained previously. The SPRING software, a free GIS (geographic information system) with image processing functions, spatial analysis, numerical modeling of land and spatial database query, was used in this step. The download of SPRING is available in http://www.dpi. inpe.br/spring/portugues/download.php. To contextualize the data described in the following paragraphs, the area occupied by each thematic class of all maps used was calculated. This information is presented in Fig. 4.

\subsubsection{Geological maps}

The geological data $(1: 750000)$ were obtained from the Brazilian Geological Survey, available on the website of the CPRM (available at www.cprm.gov.br). The materials present in the study area are granite, migmatite, gneiss, biotite, schist, metagabbro, monzogranite, mylonite, leucogranite, orthogneiss and unconsolidated sediments (alluvium, colluvium). The main geological units in the study area are migmatite/gneiss and biotite (about $30 \%$ for each one).

\subsubsection{Topographic maps}

The topography was considered by using the database for slope (declivity) and horizontal and vertical curvatures, provided by the TOPODATA project (Valeriano, 2005) and available in http://www.dsr.inpe.br/topodata, with $30 \mathrm{~m}$ spatial resolution, which is a product of the SRTM (Shuttle Radar Topography Mission).

The vertical curvature corresponds to the concave/convex character of the terrain. Analyzing the horizontal curvature of the terrain, the classes are distributed evenly (Fig. 4), unlike the vertical curvature, in which extreme classes are those that occur more (very convex and very concave). The very concave class occupies approximately $50 \%$ of the study area. Regarding the slope of the terrain, the study region appears with about $70 \%$ of its area having strongly wavy 
and mountainous classes. This characteristic is also strongly linked to the triggering of shallow landslides, mainly due to the relationship with pedogenesis of shallow soils and the favoring of sub-surface flow.

\subsubsection{Soil maps}

A soil map on a 1:500000 scale was acquired from the IAC (Agronomic Institute of Campinas), produced by Oliveira et al. (1999). Soil or altered mantles are responses to the conditions imposed by (physico-chemical) agents in rock weathering, providing zones of different resistances and permeabilities. The classes present in the study areas are described below: Haplic Cambisol (CX); Spodosol Ferrocarbic (ES); Salic Gleysol (GZ); and red-yellow Latosol (LVA). By the scale of the used map, the predominant class in the region is the Cambisols (close to $80 \%$ of the study area), which is a young residual soil generally characterized by a sandy fraction in greater proportion than the clay fraction (low weathering), slight thickness and good internal permeability. Because they are located on steep slopes, the runoff is more favored than infiltration. This fact reduces the amount of water that percolates into the soil and the rock matrix, so its features are closely related to the local lithology.

Importantly, the variability of soils in the study area with rugged terrain is very large, so different types can be found on slopes that are close together or even at different levels of the same slope (top, ramp and base). Due to the scale of soil map, these features may not be reflected. On the soil map at a 1:500000 scale, only the predominant soil types on a regional scale have been ranked, which is not always recommended for susceptibility mapping studies. However, it is known that the soil reflects the lithological and topographical characteristics, because these factors are essential to the physical and chemical weathering and hence their pedogenesis. Therefore, the use of these other variables (horizontal and vertical curvature, slope, and lithology) will help to minimize potential uncertainties derived from the soil map. This is an advantage in the use of map algebra techniques, which allow the final result to also reflect that there are interrelationships between the variables used.

\subsubsection{Land use and land cover map}

The land use and land cover map was obtained based on images of the LISS (Linear Imaging Self-Scanner) III sensor, onboard the Resourcesat satellite, for the year 2012, which are also provided by INPE (National Institute for Space Research - INPE; available at http://www.dgi.inpe.br/CDSR/).

The supervised classification and the graphic edition for the correction of the commission and omission errors were utilized. The final map, including agriculture, urban area, Eucalyptus, forest, mangrove, pasture, restinga and bare soil classes, was generated. When analyzing the spatial distribution of these classes (see Fig. 4), there is a predominance of the forest class, which represents preserved areas of natural vegetation (Mata Atlântica) almost always located in regions of rugged relief and hilltops. On the other hand, in the flat regions closer to the coast, intense processes of conversion of land use are observed, so that the urbanization process becomes widely distributed and occupies more than $8 \%$ of the total study area.

\subsection{Spatial database preparation and thematic classes weighting}

Each class of the six thematic maps (land use and land cover, geological, soil, slope, vertical and horizontal curvatures) was assessed by landslides susceptibility standpoint, evaluating their particularities with regard to favor or mitigate the triggering of shallow landslides. The assumptions for this assessment were scored in previous items, taking into account all the physical processes involved in the destabilization of slopes by shallow landslides. A referenced study done to treat this type of weighting analysis for places in Brazil was developed by Crepani et al. (2001). The authors evaluated some thematic maps (soils, geology, topography, land use), previously obtained for some parts of the Brazilian territory, and weighting factors were associated from assumptions made by several experts from different scientific area, taking into account the specificities related to physical weathering Brazilian soils and destabilization of slopes. The same criteria was used in the present study, and, for the classes not evaluated by Crepani et al. (2001), the weighting factors were determined after consenting to different analyses made by the authors of this study - a geotechnical engineer, a forestry engineer and an expert on natural disasters - as well as other related studies (Fernandes and Amaral, 1996; Kannungo et al., 2006; Binda and Bertotti, 2007; Vieira et al., 2010).

Prior to applying the fuzzy gamma technique, all classes of thematic maps were weighted in relation to the susceptibility. The weights range from 0 to 1 , where 0 indicates classes with no relation to shallow landslide triggering, and 1 indicates classes with features strongly linked to the destabilization processes of slopes. This weighting transforms the thematic maps on a numerical grid ranging from 0 to 1 .

\subsubsection{Weighting of geological classes}

The geological map was acquired in shape-file format and has different types of information, including the lithological type in the layer closest to the Earth's surface. The weights were based on rock types present in this layer, and related to the study conducted in Brazil by Crepani et al. (2001), where the authors evaluated each lithology regarding their probability of triggering landslides. Basically, igneous rocks had lower probabilities of shallow landslides, because they are less weathered than the others. Metamorphic rocks were considered intermediate, and sedimentary rocks were more prone to landslides (see Table 3). To set different weights for 
Table 3. Evaluated data and their weights associated with landslide susceptibility.

\begin{tabular}{|c|c|c|c|c|c|}
\hline \multicolumn{2}{|l|}{ Theme } & \multirow[t]{2}{*}{ Weight } & \multicolumn{2}{|l|}{ Theme } & Weight \\
\hline \multirow[t]{2}{*}{ Geology } & \multirow{4}{*}{$\begin{array}{l}\text { Type of rocks } \\
\text { Igneous }\end{array}$} & & \multicolumn{2}{|c|}{ Vertical/horizontal curvature } & \\
\hline & & & Very convex & rery divergent & 0.2 \\
\hline \multirow[t]{2}{*}{ Granite } & & 0.37 & Convex/dive & gent & 0.3 \\
\hline & & & Retilineous/ & & 0.5 \\
\hline Migmatite, gneiss & \multirow[t]{8}{*}{ Metamorphics } & 0.43 & Concave/co & ergent & 0.8 \\
\hline Biotite & & 0.57 & Very concav & very convergent & 1.0 \\
\hline Schist & & 0.67 & & & \\
\hline Metagabbro & & 0.70 & Slope & Class & \\
\hline Monzogranite & & 0.60 & $>45^{\circ}$ & Mountainous & 1.0 \\
\hline Mylonite & & 0.77 & 20 to $45^{\circ}$ & Heavy undulation & 0.8 \\
\hline Leucogranite & & 0.50 & 8 to $20^{\circ}$ & Undulation & 0.5 \\
\hline \multirow[t]{2}{*}{ Orthogneiss } & & 0.47 & 3 to $8^{\circ}$ & Smooth undulation & 0.3 \\
\hline & \multicolumn{2}{|l|}{ Sedimentary } & 0 to $3^{\circ}$ & Plane & 0.2 \\
\hline \multirow{3}{*}{\multicolumn{2}{|c|}{$\begin{array}{l}\text { Sediments uncosolidated: } \\
\text { alluvium, colluvium }\end{array}$}} & 1.00 & & & \\
\hline & & & \multirow{2}{*}{\multicolumn{2}{|c|}{$\begin{array}{l}\text { Land use } \\
\text { Agriculture }\end{array}$}} & \\
\hline & & & & & 0.8 \\
\hline Soil class & \multicolumn{2}{|l|}{ Acronym } & \multicolumn{2}{|l|}{ Urban area } & 1.0 \\
\hline Haplic Cambisols & $\mathrm{CX}$ & 0.80 & \multicolumn{2}{|l|}{ Eucalyptus } & 0.7 \\
\hline Spodosol ferrocarbic & ES & 0.55 & \multicolumn{2}{|l|}{ Roads } & 0.9 \\
\hline Salic Gleysol & GZ & 0.60 & \multicolumn{2}{|l|}{ Pasture } & 0.7 \\
\hline Red-yellow Latosol & LVA & 0.40 & \multicolumn{2}{|l|}{ Restinga } & 0.5 \\
\hline \multirow[t]{3}{*}{ Urban } & URB & 1.00 & \multicolumn{2}{|l|}{ Mangrove } & 0.2 \\
\hline & & & \multicolumn{2}{|l|}{ Bare soil } & 0.9 \\
\hline & & & \multicolumn{2}{|l|}{ Forest } & 0.4 \\
\hline
\end{tabular}

each type of igneous rock, the criterion used refers to the type of soil that could be developed by such a lithology, and also takes into account the heterogeneity of the pedological substrate that, in turn, may generate different patterns of infiltration. The alluvium and colluvium classes received the highest weight (1.0), due to the characteristics of the shallow landslides described previously. Especially when there are slopes with lateral cuts (for road construction, for example), these sediments tend to move easily when there is a flow of underground water. This movement of sedimentary deposits is sufficient to break the static friction conditions of the soil mass, triggering the shallow landslides.

\subsubsection{Weighting of topography: slope, horizontal and vertical curvatures}

The topography was addressed through horizontal and vertical curvatures and the slope. The horizontal curvature refers to the divergent/convergent character of flows of matter on the ground when analyzed on a horizontal projection. This curvature is related to the processes of migration and accumulation of water, and minerals and organic matter in soil caused by gravity, and plays an important role in the resulting water balance and pedogenesis process (Veloso, 2002). Terrain with convergent profiles presents a higher risk of sliding incidents than divergent profiles (Fernandes and Amaral, 2003).
Several geomorphological studies have called attention to the role played by the concave portions of the relief (hollows) on the convergence of water streams, both surface and sub-surface, favoring the development of soil saturation conditions and ultimately the generation of shallow landslides (Tsukamoto et al., 1982; Reneau et al., 1984; Crozier and Vaughan, 1990; Dietrich and Dunne, 1993; Fernandes et al., 1994, 2004). Thus, convergents (horizontal curvature) and concave (vertical curvature) relief forms received the highest weights in for susceptibility analysis (Neuhäuser and Terhorst, 2007; Brenning, 2005; Talebi et al., 2008). The slope map was divided into 5 classes in accordance with those suggested by Binda and Bertotti (2007) and Kanungo et al. (2006), with weights attributed to each slope class. The steeper slopes are more disposed to landslides and is one of the key factors in inducing slope instability. As the slope angle increase, shear stress in soil or other unconsolidated material generally increases as well. Gentle slopes are expected to have a low frequency of landslides because of generally lower shear stress associated with low gradients (Anbalagan, 1992). 


\subsubsection{Weighting of soils}

For the different types of soils, the weights were also based on the study of Crepani et al. (2001). The higher or lower landslide susceptibility of a soil depends on many factors, such as its structure, the type and amount of clay (related to cohesion and a low angle of friction), permeability, soil depth, and the presence of impermeable layers (Lee and Min, 2001). For natural landscape units associated with stable conditions, the weights assigned to the soils must be low (less than 0.5), and in this study are represented by the class of the Latosols soil type. Analyzing by geotechnical standpoint regarding the shallow landslides, this type of soil is unfavorable for promoting a translational rupture, because these are well developed soils, with great depth and porosity, and cohesive, besides having considerable homogeneity between the layers. Therefore, Latosols are considered the type whose soil materials are the most decomposed, and are referenced as old or mature soils. All these characteristics result in a weight of 0.4. Spodosol ferrocarbics are present in areas with low slopes. This soil type is characterized chiefly by the presence of a spodic $\mathrm{B}$ horizon formed by the concentration of organic matter; it is deep and may have an E horizon. The Gleysols are also present in areas with lower slopes. Its main characteristic is the presence of a gley horizon, which characterizes poorly drained soils. Therefore, both soils (Gleysols and Spodosols) received intermediate weights for susceptibility to landslides ( 0.60 and 0.55 , respectively). For natural landscape units associated with susceptible conditions, soils occur whose assigned values are near 1.0. They are considered young soils in the initial phase of formation, because they are still developing from source materials recently deposited, or because they are located in places of high slopes, where the rate of soil loss is equal to or greater than the speed transformation of rock into soil (Coelho-Neto et al., 2009). The Cambisols are in this group, found in practically the whole study area on the hill slopes and the mountainous region. Of some characteristics related to shallow landslide triggering, it is important to highlight its thin profile and the high quantity of the sands, which promote and facilitate the water flow on the sub-surface. A class named "urban soils" refers to the portion of the study area that is currently impermeable due to the creation of urban spaces and their related infrastructure. Therefore, this class does not represent a specific type of soil, but should be included as a thematic class, as these locations will receive rainwater and promote runoff or infiltration flow, depending on the local characteristics of the urbanization process. In the study region, the value of 1.0 refers to the fact that the conditions of the urbanization process in locations close to the slopes favor the occurrence of shallow landslides. It is common to find locations where the infrastructure is poor and often ends up creating preference paths for runoff and water accumulation, besides promoting overload situations on cut-and-fill slopes, which could destabilize them.

\subsubsection{Weighting of land use and land cover}

For land use and land cover map, the weights assigned to each vegetation class depend on the type of coverage. The volume of material removed and transported by rainwater is related to the density of vegetation cover and the slope declivity, and with vegetation removal (Veloso, 2002). These processes become more intense, especially in areas with steep slopes (Vieira et al., 2010). The land cover class 'forest' is the one that presents the lowest weight $(0.4)$ for land use classes (see Table 3 ). The forest cover, along with the understory, adds to the soil good interception of rainwater, preventing runoff and, consequently, the landslide processes. Furthermore, the roots, especially when they are intertwined, increase soil cohesion (Tatizana et al, 1987b; Kuriakose, 2006). In areas with Eucalyptus plantations, the soil is not fully protected if compared with areas of forests, since not always there is the presence of understory, which makes the soil more susceptible to landslide. Other types of cover, such as mangroves and sandbanks, received low weight due to the fact that they are developed along the time in flatter regions and, therefore are less susceptible to landslides. The "bare soil" class receives a high score (0.9) due to removal of natural vegetation cover. With this removal, are also lost the stabilizing factors of the forests, previously explained. Moreover, the exposure of the soil increases the intensity of the solar radiation on the surface and in tropical regions, after a rainy period, the surface layers are dried faster than deeper. This difference in moisture throughout the soil profile promotes different flows of water in the subsurface, which is one of the factors that induce the triggering of shallow landslides. Agricultural areas also received weights close to 1.0 , because the cultures usually present a period in which the soil is exposed during plant development, thereby increasing the susceptibility of the area.

The "roads" and "urban area" classes received the highest weights ( 0.9 and 1.0 , respectively) because they are places with high landscape alteration, and may accelerate and/or induce processes of mass movements, as explained previously. Note that our method considers the urban area to be a strong contributing factor to the destabilization of slopes, while forests and natural areas remain the most stable slopes. These relationships are inherent to the study area, because the urban areas on the slopes have been occupied rapidly during the last few decades and years without any planning, so that there are too many factors that increase the susceptibility of landslides, such as that the urban system drainage is deficient, the houses have foundations supported on the shallow layers of the soil (not on the rocks), and there are points with no sewage uptake, and so the wastewater favors the erosion in the foothills of slopes.

The susceptibility values for all classes present in the different themes addressed are presented in Table 3. 


\subsection{Susceptibility map construction: the fuzzy gamma technique}

Due to the uncertainties arising from the materials and parameters used in the landslide assessments, and the nonlinear character of the landslide phenomena, utilization of the fuzzy gamma technique can be considered an effective approach when insufficient data exist statistically or when it is difficult to evaluate the landslide susceptibility by mathematical models, especially for large areas (Ercanoglu and Gokceoglu, 2004).

The six themes were combined to generate a final susceptibility map using the fuzzy gamma operator. The fuzzy operator was introduced by Zadeh (1965) and allows a more realistic treatment of imprecise and subjective data that are part of analyses of physical environments. The fuzzy theory employs the idea of member functions and expresses the degree of membership with respect to some attribute, in this case landslide susceptibility. The fuzzy gamma operator is presented in Eq. (1).

$\mu_{\text {combination }}=\left(1-\prod_{i=1}^{n} \mu_{i}\left(1-\mu_{i}\right)\right)^{\gamma} \cdot\left(\prod_{i=1}^{n} \mu_{i}\right)^{1-\gamma}$

$\mu_{i}$ is the fuzzy membership function for the $i$ th map (theme), $i=1,2, \ldots, n$ maps (themes) are to be combined, and $\gamma$ (gamma) is a parameter within the range (0 to 1). Discerning choice of $\gamma$ produces output values that ensure a flexible compromise between the "increase" tendencies of the fuzzy algebraic sum and the "decrease" effects of the fuzzy algebraic product.

For Bonham-Carter (1994), the values in the range from 0 to 0.35 show a "diminutive" character; i.e., they are always less than or equal to the smallest input fuzzy member. The values in the range from 0.8 to 1.0 have an "increasing" character, in which the output value will be equal to or greater than the value of the largest fuzzy member input values, and the range from 0.35 to 0.8 does not have an "increasing" or "diminutive" character.

Susceptibility maps were generated with values of gamma equal to 0.8 . These input values do not have a diminutive or increasing character, and were used in works from Lee (2007), Pradhan et al. (2009) and Pradhan (2010). Other reasons for this choice are the studies developed by the same authors of this paper in other study areas (Canavesi et al., 2013; Alvalá et al., 2013), which found that 0.8 provides the best results for representing shallow landslide phenomena in the same region when compared with other values.

The map algebra was implemented by LEGAL (Spatial Language for Algebraic Geoprocessing), a query and manipulation spatial language that performs operations on spatial data through the SPRING software. Thus, each thematic class received its corresponding weight so that information could be crossed by the fuzzy model and generate the susceptibility map. As a result, a gridded map from the whole study area was generated with values from 0 to 1 , representing the shallow landslide susceptibility. This gridded map was sliced into five equidistant susceptibility classes, with a gap equaling 0.20 , from 0 to 1.0. Finally, aiming at a better visualization of the results, a "mask" was created to filter the mapping areas with slopes less than $10 \%$. This step is based on the regional historical data and consulted literature, which indicate that there are no occurrences of landslides for these cases.

\subsection{Validation of results}

The application of techniques for mapping susceptibility to landslides requires the validation step in order to evaluate the results, which is generally done by comparing it with some prior real data, such as images, hazard reports and, mainly, location of scars (Begueria, 2006; Huabin et al., 2005). As the methodological proposal of this study includes techniques and data obtained from the public domain, the validation of the results of the fuzzy gamma technique was not done through landslide-scar maps, that is, a validation technique commonly used in related studies (Vieira et al., 2010; Dymond et al., 2006; Ercanoglu and Gokceoglu, 2004; Vahidnia et al., 2010). Alternatively, the CPRM risk sectors were used as units of validation, since in Brazil, there are no free data of landslide-scars mapped or monitored. It would be possible to perform landslide-scar mapping for this study, but we consider this mapping to be a meticulous and detailed work that becomes unfeasible when the study scale is regional or municipal and needs to be replicated in the future. It should be emphasized that Brazil is a country with continental dimensions (an area equal to $8500 \mathrm{~km}^{2}$, and with $5565 \mathrm{mu}-$ nicipalities), and this demands urgent risk mappings, which makes the use of landslide-scar surveys unfeasible from a practical view. Furthermore, the present methodology is focused on identifying high susceptibility within inhabited areas. Therefore, it is not in our interest to use landslide-scar sites, because most scars are in forested areas or in locations that present no risk to the population.

In this context, a base of spatial data of risk sectors mapping was used to validation step, which was developed by CPRM and provided by CEMADEN (Brazilian Centre for Monitoring and Warnings of Natural Disasters). CEMADEN uses these risk sectors as the basis for decision-making in the possible warnings of landslide disasters, through monitoring meteorological extreme events for some selected municipalities. The risk sectors correspond to spatial polygons delimited by experts (geologists, civil engineers, geotechnical, and others), which include urban areas where landslides offer risk to the population. The procedures adopted for the identification of risks in urban areas were carried out in detailed scale, ranging from $1: 2000$ to $1: 1000$, using also remote sensing and cartographic databases, as well as available literature for preliminary recognition. Technicians and specialists in civil defense from municipalities, together researchers 


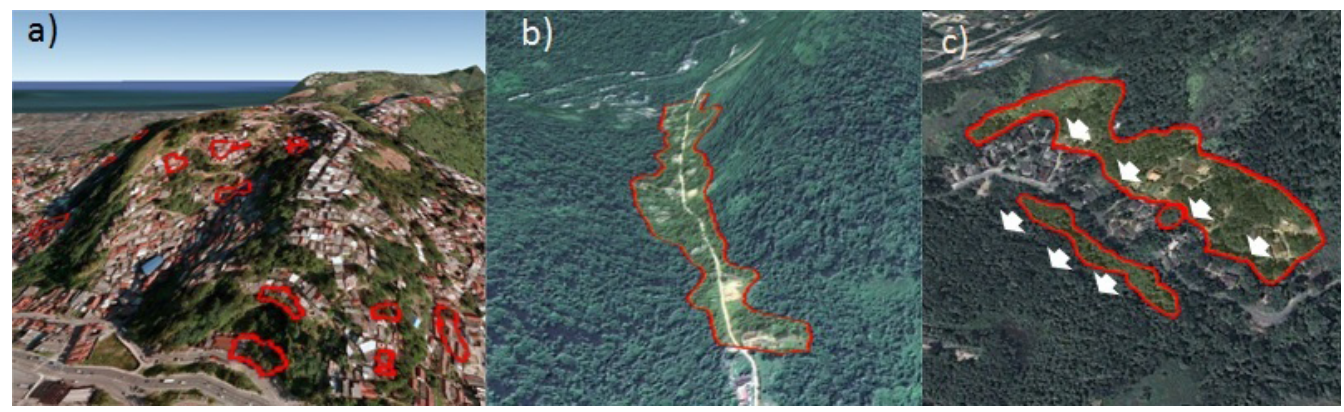

Figure 5. Three main types of risk sectors (red lines) found in the CPRM mapping. Examples of (a) typology 1, (b) typology 2, and (c) typology 3. The images are from Google Earth $^{\circledR} 2013$.

from CPRM, (including pairs of geologists and/or geologists or hydrologists and geographers engineers), make the field survey of the cities, especially to delineate the urban and periurban areas, to identify the sectors of high and very high risk to mass movements. The delineation of risk areas is made through a polygon surrounding the portion of a hillside with potential to suffer some sort of natural or induced process, which can cause damage, and is bordered on images and/or photographs. Thus, the survey is a detailed work, based on a large scale and in situ works. It is important to note that CPRM risk sectors correspond to locations visited in situ that show evidences of possible mass movements (cracks/signs of soil subsidence, scars, inclined trees and/or lampposts, etc.) and that threaten urban occupations. Areas of natural preservation, agricultural areas, pastures, as well as urban areas in conditions that still did not present any evidence of mass movements were not included in the CPRM survey.

Analyzing the CPRM database, it was possible to identify different designs and types of risk sectors. Thus, in order to use the risk sectors mapped by CPRM for the validation step correctly, they were classified into three different typologies: typology 1: steep slopes, predominantly with urban constructions, which present a risk of landslide slip with residences; typology 2: areas with smooth/undulated relief that have activities and/or urban occupations (roads and buildings) at risk of landslides that may occur on the slopes above or below where they are; and typology 3: steep slopes, predominantly uninhabited and/or preserved, generally forested, which present risks of landslides and, consequently, reach buildings nearby (Fig. 5).

The classification into typologies is important, because not all risk sectors represent locations where the fuzzy gamma weighting (Table 3) will predict with high susceptibility. In the case of typology 2, for example, the risk sectors do not represent susceptible areas, but indicate stable slopes or flat locations that may be hit by landslides nearby. Therefore, for the validation, it is necessary to filter these typologies by using only representative risk sectors that must indicate high susceptibility. Otherwise, the use of sector risks with different characteristics may decrease the quality of the results.
After the generation of the map of susceptibility by the fuzzy gamma technique, the matrix file is transformed into a polygon shape file. Using a GIS, the area $\left(\right.$ in $\mathrm{m}^{2}$ ) of each susceptibility class was quantified; histograms were obtained, and they were related to the polygons of risk sectors. Through simple GIS functions (such as the "Clip"), it was possible to identify and quantify the susceptibility classes that are inside the polygons that form the risk sectors.

For the results, it is expected that the risk sectors must be composed mostly of the higher susceptibility classes. Thus, the proportions of areas occupied by each class of susceptibility inserted into the risk sectors were quantified, and are represented by the "risk concentration" (RC) index. RC is thus the frequency (percentage) of each susceptibility class in the risk sector boundaries. Another index was also used: "risk potential" (RP). The RP index is the ratio between the area occupied by each susceptibility class inside risk sectors, and the total area of each susceptibility class inside all urban boundaries of the study area. In some studies in the literature, similar indexes are used, generally named "landslide concentration (LC)" and "landslide potential", but which refer to the same ratio. The different nomenclature is due to the ordinary use of a landslide-scar map instead of a risk sector (or risk areas), and can be used for comparison between different studies.

Besides these analyses, other approach was adopted, based on the "risk levels" terminology used by CPRM, and considered by some recent studies (Listo and Vieira, 2012; Pascarelli et al., 2011). The classification considering "risk levels" provided by CPRM considers a hierarchical categorization of risk sectors, regarding the probability of landslide occurrence and its potential impacts. This classification was made by experts from CPRM, based on predefined criteria and findings on examination in loco. Basically, it is an analysis that evaluates the predisposing geological and geotechnical conditions and the level of human intervention on each occupied slope, which takes into account such factors as the type of terrain, signs of soil movement (step abatement), cracks in houses, inclined poles or trees, erosion at the bases of slopes, length of slopes, and others. The classes range 
Table 4. Criteria for defining the probability of occurrence of the destructive processes of landslides on occupied slopes (version used in southeastern Brazil by CPRM).

\begin{tabular}{ll}
\hline Risk level & Description \\
\hline R1 (low to no risk): & $\begin{array}{l}\text { The geological and geotechnical predisposing factors (slope, terrain types, etc.) and the } \\
\text { level of intervention in the sector have a low potential for landslide process } \\
\text { development. There is no evidence of destructive process development on the slopes. } \\
\text { The least critical condition. Maintaining existing conditions, the } \\
\text { occurrence of landslide events is not expected in the rainy period. }\end{array}$ \\
\hline R2 (medium): & $\begin{array}{l}\text { The geological and geotechnical predisposing factors and the level of intervention } \\
\text { in the sector have a low potential for landslide process development. Note the presence of } \\
\text { some evidence of instability in slopes, however incipient. Maintaining existing } \\
\text { conditions, the possibility of landslide events during heavy rains and } \\
\text { prolonged episodes during a rainy period is reduced. }\end{array}$ \\
\hline R3 (high): & $\begin{array}{l}\text { The geological and geotechnical predisposing factors and the level of intervention in } \\
\text { the sector are high potential for the development of processes of landslides. The } \\
\text { presence of significant evidence of instability (cracks in the soil, etc.). Maintaining } \\
\text { existing conditions, the occurrence of landslide events during heavy } \\
\text { rains and prolonged episodes is quite possible during a rainy period. }\end{array}$ \\
\hline $\begin{array}{l}\text { The geological and geotechnical predisposing factors and the level of intervention in } \\
\text { the sector are high potential for the development of processes of landslide. The } \\
\text { evidence of instability (cracks in the soil, fissures in houses or containment walls, trees } \\
\text { inclined, landslide scars, erosive features, etc.) are significant and are present in large } \\
\text { numbers and/or magnitude. The most critical condition. Maintaining existing } \\
\text { conditions, the occurrence of landslide events during heavy rains and } \\
\text { prolonged episodes is very possible during a rainy period. }\end{array}$ \\
\hline
\end{tabular}

Source: Ministério das Cidades/Cities Alliance (2006)

from R1 (less critical, low probability of occurrence) to R4 (most critical, high probability of occurrence). For these reasons, we chose to analyze separately the risk sectors of each "risk level", and to calculate the distribution of susceptibility classes provided by our mapping. Even though the CPRM categorization has been made from in loco evidence, the aim of this comparison is to evaluate the contributions and shortcomings of the proposed methodology. The hypothesis is that the less critical sectors (R1 and R2) must present a minor proportion of high-susceptibility classes compared to the most critical sectors (R3 and R4). The purpose of CPRM in using the risk level classification is to support civil defense, urban managers, as well as CEMANDEN, which provides the landslide alerts during the rainy season. Therefore, this CPRM classification is not a scientific product prepared for academic purposes, but can be embedded perfectly in the validation step of our proposed methodology. Importantly, the methodology presented in this study does not correspond to the stages in the definition and classification of risk sectors, which have been developed by the CPRM survey. The description of the risk levels is presented below (Table 4). In this analysis, the aim is to find correlations between risk levels and landslide susceptibility classes (the higher the risk level, the higher the susceptibility class).

\section{Results and discussions}

\subsection{General discussions for shallow landslide susceptibility maps}

In general, the final results (shown in Fig. 6) indicate that the spatial patterns of susceptibility to shallow landslides are in accordance with what is expected; that is, (i) hilltop regions, forested and preserved slopes, and sedimentary deposits (usually very close to the coast, where $90 \%$ of the urban areas are located) mostly have a lower susceptibility; (ii) slopes with human activities, usually delineated by mass movements that occurred in the past (e.g., a very convex curvature), with shallow soils or average depth, show up, mostly, with higher susceptibility.

The frequencies of occurrence for each susceptibility class for the whole study area were calculated, and are presented in Fig. 7.

The results indicate the predominance of the "medium" susceptibility class $(44.7 \%)$, followed by the classes with "high" (30.8\%) and "low" (23.9\%) susceptibilities. The "very low" susceptibility class represents only $0.1 \%$ of the study area, while the "very high" class occupies a slightly higher proportion $(0.5 \%)$. This trend of the most critical susceptibility classes (high and very high) occupying a larger 

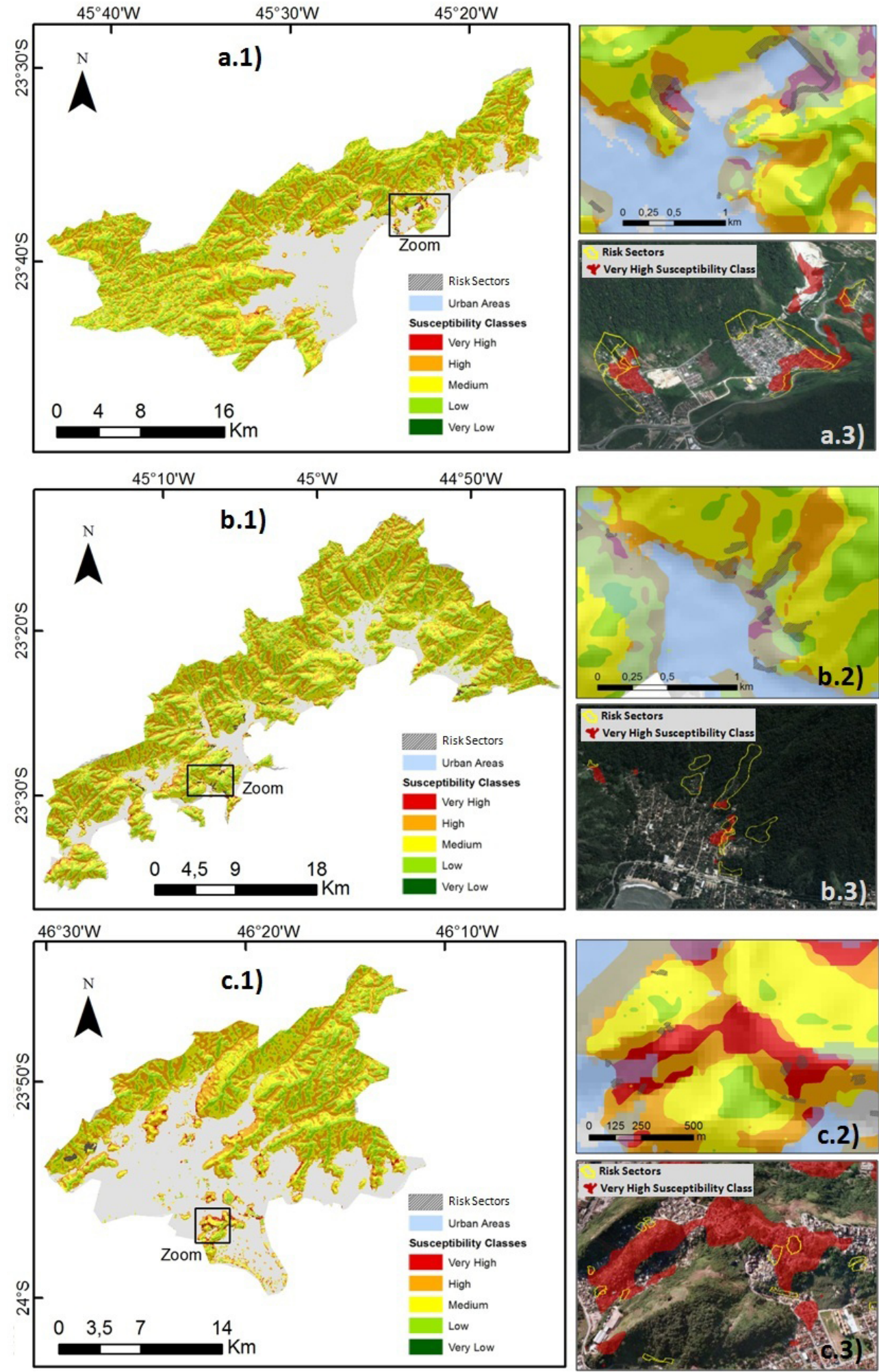

Figure 6. Landslide susceptibility mapping using the fuzzy gamma technique ( $\gamma=0.8)$. Municipalities of (a.1) Caraguatatuba, (b.1) Ubatuba and (c.1) Santos and Cubatão. The detailed maps (a.2, b.2, c.2) are examples of cases with overlapping between risk sectors and the most susceptible classes. Google Earth $^{\circledR}$ images (a.3, b.3, c.3) represent the same location as the maps zoomed in, but only the "very high" susceptibility class is highlighted (in red polygons), along with the mapped risk sectors (in yellow lines). 


\begin{tabular}{|c|c|c|}
\hline \multicolumn{3}{|c|}{ Study Area Profile } \\
\hline Classes & Area (ha) & \\
\hline Very Low & 191 & $0,1 \%$ \\
\hline Low & 38571 & $23,9 \%$ \\
\hline Medium & 72073 & $44,7 \%$ \\
\hline High & 49649 & $30,8 \%$ \\
\hline Very High & 770 & $0,5 \%$ \\
\hline Total & 161254 & $100 \%$ \\
\hline
\end{tabular}

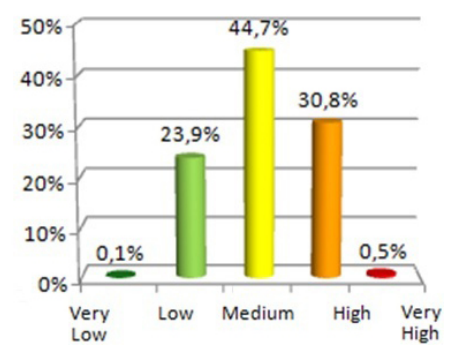

Figure 7. Frequencies of occurrence for each susceptibility class for the whole study area.

proportion area than the more stable classes (low and very low) is consistent with that expected for the great slopes of the Serra do Mar and its rugged terrain, as well as the expansion of urban areas towards the hillsides.

A detailed analysis of the risk sector location and the susceptibility mapping is consistent with what is expected. Visually, the risk sectors are located in areas more susceptible to landslides (represented by the "high" and "very high" classes). The "risk concentration" (RC) index was calculated for all 233 risk sectors (which total an area of $282.44 \mathrm{ha}$ ), and correspond to the susceptibility class distributions of frequency inside them. This step was done for three typologies of risk sectors, in order to have a differentiated analysis for each one (Fig. 8).

When only the risk sectors (three typologies included) are considered, the "high" and "very high" classes occupy about 56.1 and $8.6 \%$ of the areas, respectively ("Total" column in Fig. 8). These values are much higher than the average of the study area (30.8 and $0.5 \%$, respectively), which indicates a positive correlation between risk sector location and high susceptibility classes. This fact shows the accuracy of the technique used, and becomes more representative when only typology 1 is analyzed. For typology 1 , which is characterized by inhabited steep slopes, and is at risk of slipping, the two "high" and "very high" classes account together for an RC of $72.5 \%$ (60.5\% and $12 \%$, respectively).

Concerning the "low" and "medium" susceptibility classes, a negative correlation with the risk sectors was expected to be found, which should be less composed of these classes. For the whole study area analyzed, $23.3 \%$ of the area belongs to the "low" class, and $44.7 \%$ to the "medium" class (Fig. 7). On the other hand, the RC index for all risk sectors (considering three typologies) is $1.7 \%$ for the "low" class, and $33.7 \%$ for the "medium" class. These values are thus less than the ones found for the average for the study area, especially for the "low" class. Thus, this fact really shows a negative correlation for these classes and the risk sector location.

This result indicates that only an insignificant portion of the risk sector is located in the "low" susceptibility class, and this residual value of $1.7 \%$ is probably due to the different designs/drawings of the sectors. Also, this result is observed better when typology 3 is analyzed, which is the one with the largest portion in the "lower" class, with an RC equaling $6.8 \%$. Among the three typologies, this is the sector type where the risk has not been defined from the location of the urban area. In this case, the risk refers to the slopes (usually forested) that can slip and reach nearby residences. For this typology (3), the land-use class is mostly "forest" whose weight associated with this class is the lowest (0.4 - Table 3$)$. Therefore, it is common to find lower values of susceptibility for this type of sector, which justifies the highest RC for the "low" class. Although the value of $6.8 \%$ is the highest among the typologies, it should be emphasized that it is still well below the study area average $(23.3 \%)$.

Analysis of the right chart shown in Fig. 8 also corroborates the importance of risk sector classification in different typologies, which allows its use in the validation of the results, since they consider different characteristics, and which makes separate evaluation possible. While risk sectors of type 1 stand out in having the highest RC for the "very high" class, typology 3 stands out in the "low" class, and typology 2 is intermediate. This distribution is in accordance with the specifications considered for each typology.

\subsection{Rating from related studies}

The validation method described previously is commonly used in other studies for landslide susceptibility evaluation. Although there are differences between the study areas, the use of the LP/RP and LC/RC indexes allows for a comparison of the relations between one region and another. The use of the "risk sectors", as the validation unit rather than landslide scars, does not interfere in the comparative analysis, because the assumptions are the same either for LP and LC or for RP and RC: it counts up all validation units (scars or, in the present study, risk sectors), based on the assumption that these sites are inserted into classes of high susceptibility. It is very important to notice that although the proposed methodology results in a "susceptibility map", the inclusion of a land-use map (with the highest score for an urban area) turns the susceptibility evaluation into something broader that approaches a risk map. For this reason, the best validation units that can be used are the "risk sectors". Therefore, the methodology proposed could be used to indicate critical places within urbanized areas. In the present study, high susceptibility on slopes where there are urban occupations is expected to be found. On the other hand, in traditional studies designed to evaluate natural susceptibility (without human intervention), such anthropogenic factors are disregarded. Thus, the slopes considered critical in these traditional studies need to be necessarily located in the same places where there are scars. This pattern does not necessarily occur in the municipalities studied, because if some area is urbanized, it is not possible to identify scars at the present time, since it is assumed that such phenomena may occur in the future. 


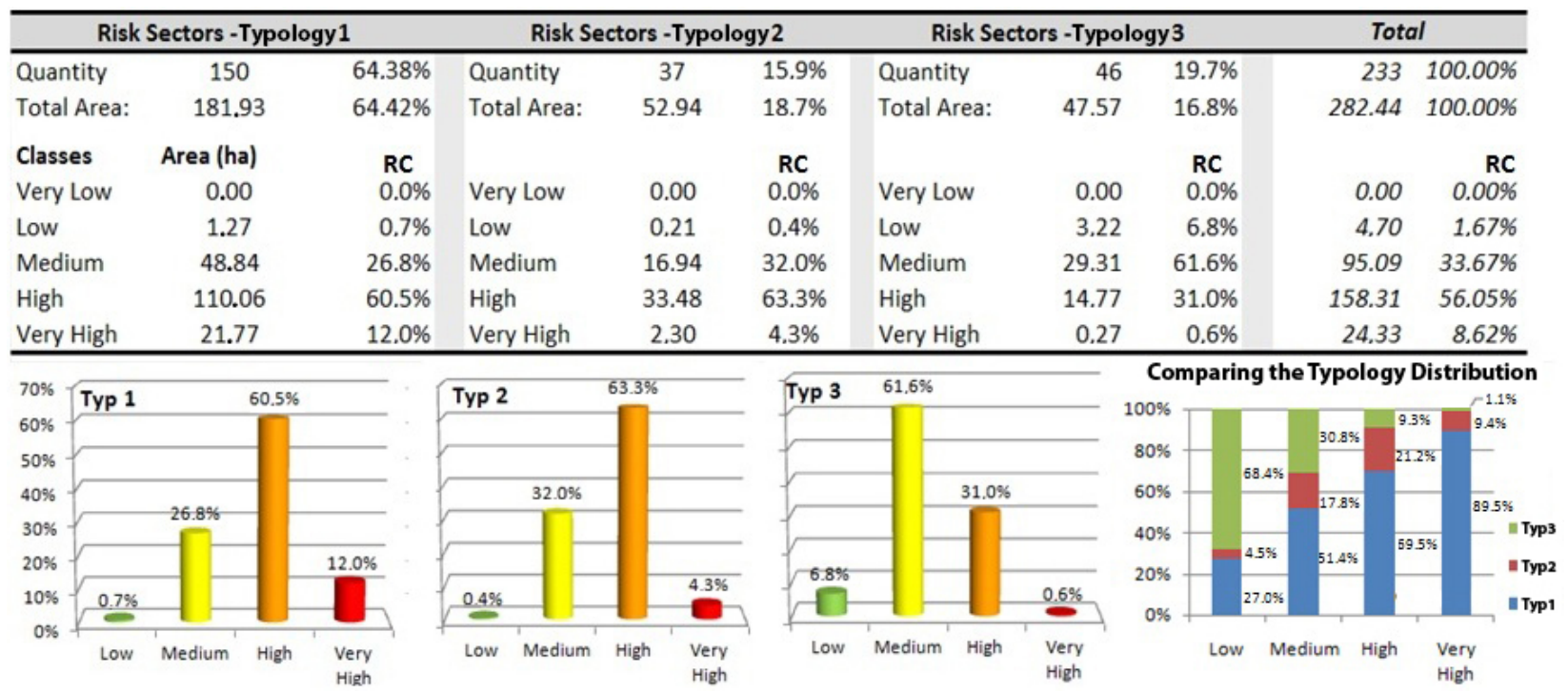

Figure 8. Frequency of susceptibility classes related to the three different typologies of risk sectors (risk concentration - RC - index). The chart on the right shows the percentage areas occupied by each susceptibility class, grouping the three typologies.

Several studies use mathematical models to predict the unstable areas (e.g., SHALSTAB, TRIGRS, SinMAP, and others) from a high-resolution digital elevation model (DEM), and considering, for validation, landslide-scar maps (Dietrich and Montgomery, 1998; Guimarães et al., 2003; Vieira, 2007; Listo and Vieira, 2012). Although the methods used involve high-resolution information, geotechnical parameters and models based on the physical phenomena of landslides, the accuracy rate found in these studies is similar to the ones found in the present study, as shown below. Moreover, most studies in the literature only analyze areas with low human intervention, or natural regions (whose watersheds are commonly used as a study area). There are few studies focusing on heavily urbanized areas as well as on addressing directly the issue of the risk.

For example, Vieira et al. (2010) conducted a study to evaluate risks in the Serra do Mar region (State of São Paulo, Brazil), considering a non-urbanized watershed and using the TRIGRS model and a high-resolution DEM $\left(4 \mathrm{~m}^{2}\right)$, besides the geotechnical parameters as the input data. In this study, the results indicated a concentration of unstable areas (defined for classes with a safety factor - SF - less than or equal to 1.00 ) above $50 \%$ within the landslide scars.

More specifically, in Vieira et al. (2010), the class most critical (SF between 0.4 and 0.8 ) occupied $20 \%$ of the scars, while the following class (SF between 0.8 and 1.0) had values around $30 \%$. For the present study, about $72 \%$ of the risk sector area belongs to the more susceptible classes (12\% in areas of "very high" and $60 \%$ in areas of "high" susceptibility). Therefore, this result is consistent with related studies that used landslide-scar maps for validation, where the most critical classes of susceptibility have concentrations between
$50 \%$ (e.g., Vieira et al., 2010) and $75 \%$ (e.g., Crosta and Frattini, 2003; Salciarini et al., 2006).

One of the studies considering a similar analysis for heavily urbanized areas in the city of Juiz de Fora, Minas Gerais State, Brazil, was performed by Zaidan and Fernandes (2009) (see too Dietrich and Montgomery, 1998; Keefer, 2000; Wang and Niu, 2010; Qi et al., 2010). They had also used a high-resolution DEM and the SHALSTAB mathematical model, and found about $19 \%$ of the total area in the classes considered unstable, with a high scar concentration (SC) index in these classes, approximately $70 \%$. In our study, $0.5 \%$ of total study area was found in the most susceptible class ("very high"), while $30.8 \%$ is in the "high" class, and the RC index (compared to the SC index) was $72.5 \%$.

Subsequently, another approach was taken by using the risk potential (RP) index for all typologies, and the results are presented in Table 5 .

For comparative purposes of the results presented in Table 5, some important studies that used related indexes were listed. The landslide potential (LP - similar to RP) index found in the study developed by Vieira et al. (2010) was approximately $5.7 \%$ for the most unstable class (FS between 0.4 and 0.8 ), and decreased to $1 \%$ for stable classes (FS between 1.5 and 7.0). Thus, the LP indicates that $5.7 \%$ of all locations identified by the model as unstable are inserted into the mapped landslide scars, and this value (higher than $5 \%$ ) is recognized in the literature as a good quality.

In another study, Listo and Vieira (2010) used the SHALSTAB model to map the landslide susceptibility in a small catchment area $\left(9 \mathrm{~km}^{2}\right)$, with a high-resolution digital terrain model (DTM) $\left(4 \mathrm{~m}^{2}\right)$ and geotechnical parameters for only 13 risk sectors evaluated. Listo and Vieira (2010) found an RC index close to $70 \%$ for the two most unstable classes 
( $41 \%$ for the most critical one), and an RP index equal to $12 \%$ for the most critical classes, reaching values below $1 \%$ for less critical classes. As shown previously, for the present study, the RP index for typology $1\left(\mathrm{RP}_{1}\right)$ was about $6 \%$, and the RC index for the two more susceptible classes shown in Fig. 8 was $72.5 \%$ (12\% for "very high", $60 \%$ for "high"). Thus, the indexes used for validation indicate a satisfactory quality of the methodology results, approaching the values found in the recent literature (higher than $5 \%$ ), even without high-resolution data being used.

\subsection{Risk level analysis}

In Fig. 9, the comparative analysis between risk levels defined by CPRM (R1, R2, R3 and R4) and susceptibility classes is shown. This analysis was performed considering only the risk sectors of typology 1 , which among the three types of classification presents the risk within the sector boundaries, thus allowing this type of analysis.

In Fig. 9, it can be seen that the higher risk rating, the lower the proportion of predicted areas with low susceptibility (low and medium). On the other hand, the most susceptible classes occupy a larger portion of these sectors (when classes "high" to "very high" are added), as shown in the following:

- $52 \%$ for $\mathrm{R} 1: 21$ sectors $(12.62 \mathrm{ha}), \mathrm{RC}=52 \%$ for "high", RC $=0 \%$ for "very high";

- $75 \%$ for R2: 51 sectors $(42.31 \mathrm{ha}), \mathrm{RC}=70 \%$ for "high", RC $=5 \%$ for "very high";

- $76 \%$ for R3: 56 sectors (64.07 ha), RC $=57 \%$ for "high", $\mathrm{RC}=19 \%$ for "very high";

- $82 \%$ for R4: 24 sectors (22.63ha), $\mathrm{RC}=78 \%$ for "high", $\mathrm{RC}=4 \%$ for "very high".

The risk sectors of categories R1 and R2 present a greater portion of the moderate class. Adding up the values of "high" and "very high" classes, these two categories (R1 and R2) also have a lower proportion. This occurrence is consistent with expectations because, although they are considered risk sectors, the description of these categories (presented in Table 4) is that, maintaining existing conditions, the occurrence of landslide events in the rainy period is not expected.

On the other hand, the description of categories R3 and R4 says that the occurrence of landslide events is very possible during heavy rains and prolonged episodes during a rainy period. Looking at Fig. 9, it is possible to note that these risk sectors have a greater proportion in the "high" and "very high" classes, as expected. However, it is important to note that the delimitation of risk sectors (made by CPRM) takes into account the reach of landslides, and not only where the phenomena could happen. For this reason, it is not always the location of these sectors that will overlap with places where the method indicated with "very high" susceptibility. Thus, there is always a portion of R3 and R4 risk sectors located in less susceptible classes (such as "high" or even "moderate"). Therefore, for cities that do not have risk mapping, locations with "very high" susceptibility should be understood as a strong indicative of risk, but that should be assessed and confirmed by filed evidences.

Interestingly, the R3 risk category showed the highest RC for the "very high" susceptibility class (19\%). Analyzing the database, it was noted that this fact occurred due to the largest risk sector found in the study area (approximately 14.2 ha $142000 \mathrm{~m}^{2}$ - in Cubatão) being almost entirely in an area with a "very high" susceptibility. Assuming that this classification for risk sectors is defined by criteria that may be considered differently by specialists (subjectivity), there is the possibility that this sector would have been considered in another class. For example, assuming that only this risk sector (that is, only 1 out of 59 sectors) had been classified in class R4, the analysis presented in Fig. 9 would be exactly as expected (R4 would have the highest percentage of the "very high" class).

\section{Conclusions}

Taking account of the current situation of Brazil and other countries that require related risk mapping urgently, two general aspects must be highlighted regarding this study. Firstly, it refers to the quality of the results achieved for a risk analysis within densely populated urban areas, which is a case relatively unexplored in landslide susceptibility modeling. Secondly, the usability and easy replicability for other study areas, due to the fact that the variables used, as thematic maps, can be acquired by any one user, and that the weighting of thematic classes can be flexible and appropriate for other areas or phenomena (e.g., floods) from prior knowledge of the local characteristics and their specificities.

The suggestion to use data from the public domain only resulted in the use of maps with different scales, some of them deficient in details for this type of analysis. However, it is known that the variables used are interrelated with each other, and the inclusion of topographic data with a resolution of $30 \mathrm{~m}$ (which represent 3 of the 6 variables used in this study: slope and horizontal and vertical curvature) was essential for the good quality of the final result. It means that, although geological and soil features were represented on a regional scale, the quality of topographic and land-use data was able to direct the model to predict different susceptibility levels in slopes that are close, which are essential for analyses made on a municipal scale. However, it would be possible to improve the result further if the geological and pedological data are on a better scale, as well as by implementing other variables that one has access to and knowledge of (e.g., geotechnical data). Thus, the advantage of the proposed methodology is that the database update can be done practically and quickly; besides, it can be optimized, so the greater the wealth and availability of data for a particular region. It is important to remember that this is a pilot study that was 
Table 5. Risk potential index calculation for typology $1\left(\mathrm{RP}_{1}\right)$, typology $2\left(\mathrm{RP}_{2}\right)$ and typology $3\left(\mathrm{RP}_{3}\right)$.

\begin{tabular}{lrlrrrrrrr}
\hline \multicolumn{1}{c}{1} & 2 & 3 & 4 & 5 & 6 & 7 & 8 & 9 \\
\hline Classes & $\begin{array}{r}\text { Total study } \\
\text { area (ha) }\end{array}$ & $\begin{array}{l}\text { Urban } \\
\text { area (ha) }\end{array}$ & $\begin{array}{r}\% \\
(2: 1)\end{array}$ & Typ 1 & $\begin{array}{r}\text { Typ 2 } \\
\text { area (ha) }\end{array}$ & Typ 3 & $\begin{array}{c}\mathrm{RP}_{1} \\
(4: 2)\end{array}$ & $\begin{array}{c}\mathrm{RP}_{2} \\
(5: 2)\end{array}$ & $\begin{array}{c}\mathrm{RP}_{3} \\
(6: 2)\end{array}$ \\
\hline Very low & 191 & 0.7 & $0.4 \%$ & 0.0 & 0.0 & 0.0 & $0.0 \%$ & $0.0 \%$ & $0.0 \%$ \\
Low & 38571 & 174 & $0.5 \%$ & 1.3 & 0.2 & 3.2 & $0.7 \%$ & $0.1 \%$ & $1.8 \%$ \\
Medium & 72073 & 4837 & $6,7 \%$ & 48.8 & 16.9 & 29.3 & $1.0 \%$ & $0.4 \%$ & $0.6 \%$ \\
High & 49649 & 7449 & $15.0 \%$ & 110.1 & 33.5 & 14.8 & $1.5 \%$ & $0.4 \%$ & $0.2 \%$ \\
Very high & 770 & 364 & $47.3 \%$ & 21.8 & 2.3 & 0.3 & $6.0 \%$ & $0.6 \%$ & $0.1 \%$ \\
\hline Total & 161254 & 12825 & $8.0 \%$ & 181.9 & 52.9 & 47.6 & & & \\
\hline
\end{tabular}
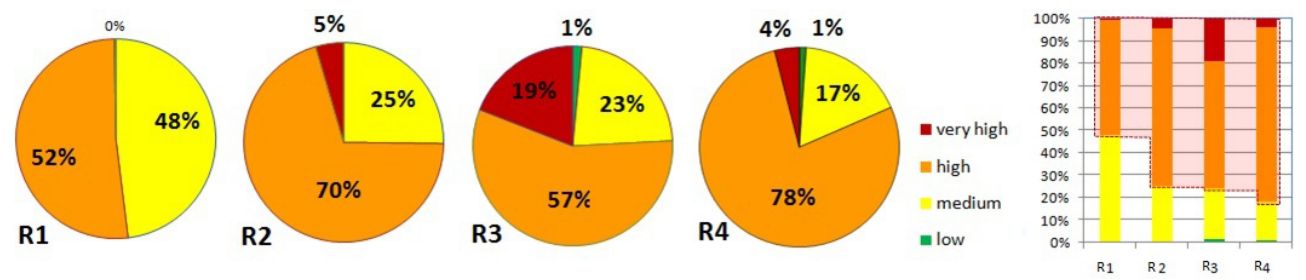

Figure 9. Susceptibility class distribution for the four risk levels used by CPRM (R1, R2, R3 and R4). Analysis for all 150 risk sectors of typology 1 . Higher risk levels are associated with larger areas occupied by the most susceptible classes (high and very high).

developed only for 4 municipalities in the state of São Paulo in order to demonstrate the quality of the methodology, but all the other 645 municipalities without susceptibility mappings can benefit from using the same database.

The proposed methodology depends substantially on the weighting step, which involves great subjectivity in their analysis, but which can be evaluated carefully so that uncertainties are not involved in the final result. The criterion definition of the weights was only possible due to the participation of different professionals working in related fields and their experience in the subject, as well the use of conceptualized studies as references. Thus, it was verified that the methodology corresponded to satisfactory results, even when compared with studies that are based on non-heuristic methods. This is an advantage of the method over others, which usually require a lot of specific data of the study area and with a high resolution, resulting in a higher cost that therefore makes it difficult to be replicated. It was noted that is very important to have knowledge and prior experience of technical fuzzy gamma to complete successfully both step weightings as the definition of the gamma parameter. Normally, it is necessary that some tests with different weights and gammas have been performed previously to assess which model provides a better adherence, but that was not described here due to this information having been provided by the conclusions of other studies developed on the same theme for Serra do Mar, by the same authors of this study (Canavesi et al., 2013; Alvalá et al., 2013). Anyway, these two steps corresponded to the core of study, and should be evaluated according to the specificities of the phenomenon to be mapped and the characteristics of their occurrence in each particular study area.

The validation of the results by using recognized indexes in the literature (RC and RP) has demonstrated that the methodology has implied satisfactory results, especially considering the scale of the work (medium resolution). Moreover, a new option for validation landslide susceptibility mapping was proposed using risk sectors instead of landslide-scar maps. In this case, the use of this evaluation unit has involved new considerations and assumptions, but this could achieve good indexes of validation, and has demonstrated the effectiveness and robustness from the assessment of such indexes in other studies. In this respect, the methodology was effective in determining the risk in urban areas, and not only the indication of susceptible areas on slopes in preserved areas, as is commonly done in other studies.

The use of RC/RP indexes, analogous to the LC/LP indexes widely used in the literature, allowed a comparison of the results and their quality. In this context, the presented methodology was able to achieve an equivalent ratio (RP or LP $>5 \%$ ), similar to the ones presented in other studies considering high-resolution data. The risk potential (RP) index found close to the value of $6 \%$ is within the average found in the literature for high-resolution studies, and means that 1 out of every 16 ha resulting from the methodology as a "very high" susceptibility class indicates one area of real risk already mapped by CPRM. Taking into consideration that there is the possibility of some cases that have not been mapped yet, this is indicative of a satisfactory quality of the results, 
and indicates that the methodology can support the management of landslide risk, as well as provide a basis for decisions as to warnings about natural disasters. This method can thus optimize the search in the field for evidence to prove the existence of the risk, and thus facilitates the mapping of risk areas in municipalities that do not have it.

The risk concentration (RC) index for typology 1 achieved a value of $72 \%$ by joining the two most susceptible classes (high and very high). Although this value of $72 \%$ is also satisfactory in the cited literature, it means that the remaining $28 \%$ of the total area indicated from the model has lower susceptibility areas that belong to the sectors of risk. In this case, it was observed that this "error" comes mainly from the subjectivity of the drawing/design stage of the sectors at risk done by the responsible agencies (CPRM). On the other hand, when analyzing the same RC index for the different risk categories (R1, R2, R3 and R4), it was found that the model provides enhanced adherence for the most critical sectors: $\mathrm{R} 3(\mathrm{RC}=76 \%)$ and $\mathrm{R} 4(\mathrm{RC}=84 \%)$. Therefore, this fact reflects a trend in the methodology to be best suited for indicating areas of risk in the most critical situations.

Regarding the emergency demands of Brazil related to the mitigation of impacts caused by landslides every year, this methodology proved robust and with high usability, not only for analyzing the risk inherent in the present day, but also for providing grants to analyze future risk areas that may result from population growth towards the slopes.

Acknowledgements. This work is part of the "Assessment of Impacts and Vulnerability to Climate Change in Brazil and Strategies for Adaptation Options" project supported by FAPESP (Fundação de Amparo à Pesquisa do Estado de São Paulo - process 2008/58161-1). Thanks are due to CNPq (National Council for Scientific and Technological Development) for financial support for the first and second authors. The authors thank CPRM for the risk sectors database. The valuable comments from Carlos Afonso Nobre are gratefully acknowledged.

Edited by: O. Katz

Reviewed by: two anonymous referees

\section{References}

Aleotti, P. and Chowdhury, R.: Landslide hazard assessment: summary review and new perspectives, Bull. Eng. Geol. Environ., 58, 21-44, 1999.

Almeida, F. F. M. and Carneiro, C. D. R.: Origem e evolução da Serra do Mar, Rev. Bras. Geocienc., 28, 135-150, 1998.

Alvalá, R. C. S., Camarinha, P. I. M., and Canavesi, V.: Landslide susceptibility mapping in the coastal region in the State of São Paulo, Brazil, in: AGU Meeting of the Americas, Cancun, 2013.

Anbalagan, R.: Landslide hazard evaluation and zonation mapping in mountainous terrain, Eng. Geol., 32, 269-277, 1992.

Atkinson, P. M. and Massari, R.: Generalised linear modelling of susceptibility to landsliding in the Central Apennines, Italy, Comput. Geosci., 24, 373-385, 1998.
Augusto Filho, O. E and Virgili, J. C.: Estabilidade De Taludes, in: Geologia de engenharia, edited by: Oliveira, A. M. S. and Brito, S. N. A., ABGE, São Paulo, 243-269, 1998.

Ayalew, L. and Yamagish, H.: The application of GIS-based logistic regression for landslide susceptibility mapping in the KakudaYahiko Mountains, Central Japan, Geomorphology, 65, 15-31, 2005.

Begueria, S.: Validation and evaluation of predictive models in hazard assessment and risk management, Nat. Hazards, 37, 315329, 2006.

Bigarella, J. J., Passos, E., Herrmann, M. L. P., Santos, G. F., Mendonça, M., Salamuni, E., and Suguio, K.: Estruturas e Origem das paisagens tropicais e subtropicais: processos erosivos, vertentes, movimentos de massa, atividade endógena, superfícies de erosão, compartimentação do relevo, depósitos correlativos e ambientes fluviais, Vol. 3, UFSC, Florianópolis, p. 556, 2007.

Binda, A. L. and Bertotti, L. G.: Geoprocessamento aplicado à análise da bacia hidrográfica do Rio Cachoeirinha, GuarapuavaPR, in: XII Simpósio Brasileiro de Geografia Física Aplicada, Natal, Brazil 12, 2007.

Bogaart, P. W. and Troch, P. A.: Curvature distribution within hillslopes and catchments and its effect on the hydrological response, Hydrol. Earth Syst. Sci., 10, 925-936, doi:10.5194/hess10-925-2006, 2006.

Bonham-Carter, G. F.: Geographic Information Systems for Geoscientists: Modelling with GIS, Pergamon, Oxford, UK, 1994.

Brenning, A.: Spatial prediction models for landslide hazards: review, comparison and evaluation, Nat. Hazards Earth Syst. Sci., 5, 853-862, doi:10.5194/nhess-5-853-2005, 2005.

Canavesi, V., Camarinha, P. I. M., Algarve, V. R., Carneiro, R. L. C., and Alvala, R. C. S.: Análise da susceptibilidade a deslizamentos de terra: estudo de caso de Paraibuna, SP, in: XVI Simpósio Brasileiro de Sensoriamento Remoto, 2013, Foz do Iguaçu - PR, Anais do XVI Simpósio Brasileiro de Sensoriamento Remoto, INPE, São José dos Campos, 5251-5258, 2013.

Carrara, A., Cardinali, M., Guzzetti, F., and Reichenbach, P.: GISbased techniques for mapping landslide hazard, in: Geographical Information Systems in Assessing Natural Hazards, edited by: Carrara, A. and Guzzetti, F., Kluwer Academic Publishing, Dordrecht, 135-176, 1995.

Chung, C. J. F. and Fabbri, A. G.: Systematic procedures of landslide hazard mapping for risk assessment using spatial prediction models, in: Landslide Hazard and Risk, edited by: Glade, T., Anderson, M., and Crozier, M. J., Wiley, Chichester, 139-177, 2005.

Coelho-Netto, A. L., Avelar, A. D. S., and Lacerda, W. A.: Landslides and disasters in southeastern and southern Brazil, Develop. Earth Surf. Proc., 13, 223-243, 2009.

Crepani, E., Medeiros, J. S., Hernadez Filho, P., Florenzano, T. G., Duarte, V., and Barbosa, C. C. F.: Sensoriamento Remoto e Geoprocessamento Aplicados ao Zoneamento Ecológico-Econômico e ao Ordenamento Territorial, p. 124, available online: http://www.lapa.ufscar.br/bdgaam/ geoprocessamento/Crepani\%20et.\%20al.pdf, last access: 7 July 2013, 2001.

Crosta, G. B. and Frattini, P.: Distributed modelling of shallow landslides triggered by intense rainfall, Nat. Hazards Earth Syst. Sci., 3, 81-93, doi:10.5194/nhess-3-81-2003, 2003. 
Crozier, M. J. and Vaughan, E. E.: Relative instability of colluviumfilled bedrock depressions, Earth Surf. Proc. Land., 15, 329-339, 1990.

Cruz, P. T., Massad, F., Kanji, M. A., and Araujo Filho, H. A.: Debris Flows in Serra do Mar, Cubatão, Brazil: Control Works and Design Parameters, CD-ROM, in: International Workshop on the Debris Flow Disaster of December 1999 in Venezuela, Caracas, p. 8,2000 .

Dietrich, W. E. and Dunne, T.: The channel head, in: Channel Network Hydrology, edited by: Beven, K. and Kirkby, M., Wiley, Chichester, 175-219, 1993.

Dietrich, W. E. and Montgomery, D. R.: SHALSTAB: a digital terrain model for mapping shallow landslide potential, Technical Report, NCASI - National Council of the Paper Industry for Air and Stream Improvement, North Carolina EUA, 1998.

Dymond, J. R., Ausseil, A. G., Shepherd, J. D., and Buettner, L.: Validation of a region-wide model of landslide susceptibility in the Manawatu-Wanganui region of New Zealand, Geomorphology, 74, 70-79, 2006.

EM-DAT: The OFDA/CRED International Disaster Database, www.em-dat.net (last access: 20 May 2013), 2013.

Ercanoglu, M. and Gokceoglu, C.: Use of Fuzzy relations to produce landslide susceptibility map of a landslide prone area (West Black Sea Region, Turkey), Eng. Geol., 75, 229-250, 2004.

Fernandes, N. F. and Amaral, C. P.: Movimentos de massa: uma abordagem geológico-geomorfológica, in: Geomorfologia e Meio Ambiente, edited by: Guerra, A. J. T. and Cunha, S. B., Bertrand, Rio de Janeiro, 123-194, 1996.

Fernandes, N. F., Coelho Netto, A. L., and Lacerda, W.: A Subsurface hydrology of layered colluvium mantles in unchannelled valleys - southeastern Brazil, Earth Surf. Proc. Land., 19, 609626, 1994

Fernandes, N. F., Guimaraes, R. F., Gomes, R. A. T., Vieira, B. C., Montgomery, D. R., and Greenberg, H.: Topographic Controls of Landslides in Rio de Janeiro: Field Evidences and Modeling, Catena, 55, 163-181, 2004.

Gao, J.: Identification of Topographic Settings Conductive to Landsliding From Dem in Nelson County, Virginia, U.S.A., Earth Surf. Proc. Land., 18, 579-591, 1993.

Greenway, D. R.: Vegetation and slope stability, in: Vegetation and slope stability, edited by: Anderson, M. G. and Richards, K. S., John Wiley \& Sons, Chichester, 187-229, 1987.

Guidicini, G. and Nieble, C. M.: Estabilidade de Taludes Naturais e de Escavação, Editora da USP, São Paulo, p. 216, 1984.

Guimarães, R. F., Montgomery, D. R., Greenberg, H. M., Fernandes, N. F., Gomes, R. A. T., and Carvalho Junior, O. A.; Parameterization of soil properties for a model of topographic controls on shallow landsliding: application to Rio de Janeiro, Eng. Geol., 69, 99-108, 2003.

Guzzetti, F., Reichenbach, P., Cardinali, M., Galli, M., and Ardizzone, F.: Landslide hazard assessment in the Staffora basin, northern Italian Apennines, Geomorphology, 72, 272-299, 2005.

Huabin, W., Gangjun, L., Weiya, X., and Gonghui, W.: GIS-based landslide hazard assessment: an overview, Prog. Phys. Geogr., 29, 548-567, 2005.

Hutchinson, J. N.: Mass movement, in: Encyclopedia of geomorphology, edited by: Fairbridge, R. W., Reinhold, New York, 688695, 1986a.
Hutchinson, J. N.: General report: morphological and geotechnical parameters of landslides in relation to geology and hydrogeology, in: Proceeduring Fifth International Symposium on Landslides, Vol. 1, edited by: Bonnard, C., A. A. Balkena, Rotterdam, the Netherlands, 3-35, 1986b.

Instituto Geológico: Desastres naturais: conhecer para prevenir, organised by: Tominaga, L. K., Santoro, J., and Amaral, R., Instituto Geológico, São Paulo, 2009.

IPMet - Instituto de Pesquisas Meteorológicas: Banco de Dados de Desastres Naturais, http://www.ipmet.unesp.br/index2.php? abre=ipmet_html/defesacivil/index.php (last access: 4 March 2013), 2013.

IPT - Instituto de Pesquisa Tecnológicas do Estado de São Paulo: Instabilidade das encostas da Serra do Mar voltadas ao parque industrial de Cubatão (SP): diagnose, soluções e ações de emergência, São Paulo, 1986.

Kanji, M. A., Cruz, P. T., and Massad, F.: Debris flow affecting the Cubatão Oil Refinery, Brazil, Landslides, 5, 71-82, 2008.

Kanungo, D. P., Arora, M. K., Sarkar, S., and Gupta, R. P.: A comparative study of conventional, ANN black box, fuzzy and combined neural and fuzzy weighting procedures for landslide susceptibility zonation in Darjeeling Himalayas, Eng. Geol., 85, 347-366, 2006.

Keefer, D. K.: Statistical analysis of an earthquake-induced landslide distribution - the 1989 Loma Prieta, California event, Eng. Geol., 58, 231-249, 2000.

Kobiyama, M., Mendonça, M., Moreno, D. A., Marcelino, I. P. V. O., Marcelino, E. V., Gonçalves, E. F., Brazetti, L. L. P., Goerl, R. F., Molleri, G. S. F., and Rudorff, F. M.: Prevenção de desastres naturais: conceitos básicos, Organic Trading, Curitiba, 2006.

Kuriakose, S. L.: Effect of vegetation on debris flow initiation: conceptualization and parameterization of a dynamic model for debris flow initiation in Tikovil River Basin, Kerala, India, using PCRaster, 2006, Thesis (Master of Science in Geo-information Science and Earth Observation) - International Institute 150 for Geo-information Science and Earth Observation and the Indian Institute of Remote Sensing (NRSA), India, p. 143, 2006.

Lee, S.: Application and verification of fuzzy algebraic operators to landslide susceptibility mapping, Environ. Geol., 52, 615-623, 2007.

Lee, S. and Min, K.: Statistical analysis of landslide susceptibility at Yongin, Korea, Environ. Geol., 40, 1095-1113, 2001.

Listo, F. L. R. and Vieira, B. C.: Mapping of risk and susceptibility of shallow-landslide in the city of São Paulo, Brazil, Geomorphology, 169-170, 30-44, 2012.

Listo, F. L. R. and Vieira, B. C.: Análise de Condicionantes Topográficos como Subsídio para Avaliação de Áreas de Risco a Escorregamentos Rasos, Revista de Geografia, v. esp., 174-187, 2010.

Marcelino, E. V., Nunes, L. H., and Kobiyama, M.: banco de dados de desastres naturais: análise de dados globais e regionais, Caminhos de Geogr., 6, 130-149, 2006.

Massad, F.; Cruz, P.T. ; Kanji, M.A. and Araujo Filho, H. A.: Concepção e função das obras de controle de debris flows, construídas em Cubatão, S. Paulo, Brasil, in: 9. Congresso Nacional de Geotecnia, 2004, v. 3, Aveiro, Portugal, Actas do 9. Congresso nacional de geotecnia - Passado, Presente e Futuro da Geotecnia, Aveiro, Portugal, Universidade de Aveiro, Aveiro, Portugal, 155-164, 2004. 
Ministério das Cidades/Cities Alliance: Prevenção de Riscos de Deslizamentos em Encostas: Guia para Elaboração de Políticas Municipais, edited by: Carvalho, C. S. and Galvão, T., Ministério das Cidades, Cities Alliance, Ministério das Cidades, Brasília, 2006.

Mousinho, M. R. and Bigarella, J. J.: Movimentos de massa no transporte dos detritos de meteorização das rochas, Boletim Paranaense de Geografia, n. 16/17, Centro de Documentação e Informação do Instituto de Geologia da Universidade Federal do Paraná, Curitiba, 43-84, 1965.

Neuhäuser, B. and Terhorst, B.: Landslide Susceptibility Assessment Using Weights-of-Evidence Applied on a Study Site at the Jurassic Escarpment of the Swabian Alb (SW Germany), Geomorphology, 86, 12-24, 2007.

Oliveira, J. B., Camargo, M. N., Rossi, M., and Calderano Filho, B: Mapa pedológico do Estado de São Paulo: Legenda expandida, Instituto Agronômico/EMBRAPA Solos, Campinas, Brazil, 1999.

Pascarelli, L., Lançone, L., Costa, R., Pires, L., Macedo, E., Mirandola, F., Checchinato, F., and Canil, K.: Mapping geological at-risk areas in the city of São Paulo: issues and results from the largest risk survey in Brazil, Proceedings of the Second World Landslide Forum, Rome, 2011.

Pierson, T. H.: Piezometric response to rainstorms in forested hillslope drainage depressions, J. Hydrol., 19, 1-9, 1980.

Pradhan, B.: Landslide susceptibility mapping of a catchment area using frequency ratio, fuzzy logic and multivariate logistic regression approaches, J. Indian Soc. Remote Sens., 38, 301-320, 2010.

Pradhan, B., Lee, S., and Buchoithner, M. F.: Use of geospatial data and fuzzy algebraic operators to landslide-hazard mapping, Appl. Geomat., 1, 3-15, 2009.

Qi, S. W., Xu, Q., Lan, H. X., Zhang, B., and Liu, J. Y.: Spatial distribution analysis of landslides triggered by 2008.5.12 Wenchuan earthquake, China, Eng. Geol., 116, 95-108, 2010.

Reneau, S. L., Dietrich, W. E., Wilson, C. J., and Roger, J. D.: Colluvial deposits and associated landslide in the northern San Francisco Bay area, California, USA. In Proceedings of 4th Internatinal Symposium on Landslides, Toronto, 425-430, 1984.

Ritter, D. F.; Kochel, R. C. and Miller, J. R.: Process Geomorphology, Dubuque, William C. Brown Pub., p. 539, 1995.

Salciarini, D., Godt, J. W., Savage, W. Z., Conversini, P., Baum, R. L., and Michael, J. A.: Modeling regional initiation of rainfall induced shallow landslides in the eastern Umbria Regional of Central Italy, Landslides, 3, 181-194, 2006.

Sassa, K., Wang, G., Fukuoka, H., Wang, F., Ochiai, T., Sugiyama, M., and Sekiguchi, T.: Landslide risk evaluation and hazard zoning for rapid and long-travel landslides in urban development areas, Landslides, 1, 221-235, 2004.

Selby, M. J.: Hillslope: materials and process, Oxford University Press, Oxford, England, p. 451, 1993.

Small, R. J.: The study of landforms: a textbook of geomorphology, Cambridge University Press, p. 486, 1970.

Talebi, A., Troch, P. A., and Uijlenhoet, R.: A steady-state analytical slope stability model for complex hillslopes, Hydrol. Process., 22, 546-553, 2008.

Tatizana, C., Ogura, A. T., Cerri, L. E. S., and Rocha, M. C. M.: Análise de correlação entre chuvas e escorregamentos - Serra do
Mar, município de Cubatão, in: Anais do 5. Congresso Brasileiro de Geologia de Engenharia, ABGE, São Paulo, 225-236, 1987a.

Tatizana, C., Ogura, A. T., Cerri, L. E. S., and Rocha, M. C. M.: Modelamento numérico da análise de correlação entre chuvas e escorregamentos aplicados às encostas da Serra do Mar no município de Cubatão, in: Anais do 5. Congresso Brasileiro de Geologia de Engenharia, ABGE, São Paulo, 237-248, 1987 b.

Tsukamoto, Y., Ohta, T., and Noguchi, H.: Hydrological and geomorphological studies of debris slides on forested hillslopes in Japan, Int. Assoc. Hydrol. Sci. Publ., 137, 89-98, 1982.

Vahidnia, M. H., Alesheikh, A. A., Alimohammadi, A., and Hosseinali, F.: A GIS-based neuro-Fuzzy procedure for integrating knowledge and data in landslide susceptibility mapping, Comput. Geosci., 36, 1101-1114, 2010.

Valeriano, M. M.: Modelo digital de variáveis morfométricas com dados SRTM para o território nacional: o projeto TOPODATA, Proceedings of XII Simpósio Brasileiro de Sensoriamento Remoto, Goiânia, 2005.

van Westen, C. J., van Asch, T. W. J. and Soeters, R.: Landslide hazard and risk zonation-why is it still so difficult?, Bull. Eng. Geol. Env., 65, 167-184, 2006.

Varnes, D. J.: Landslide hazard zonation: a review of principles and practice, UNESCO, Paris, 1984.

Veloso, A. J. G.: Importância do Estudo das Vertentes, GEOgraphia, 4, 79-83, 2002.

Vieira, B. C.: Previsão de Escorregamentos Translacionais Rasos na Serra do Mar (SP) a partir de Modelos Matemáticos em Bases Físicas, Ph.D. Thesis, Federal University of Rio de Janeiro, Brazil, 193 pp., 2007.

Vieira, B. C. and Fernandes, N. F.: Landslides in Rio de Janeiro: the role played by variations in soil hydraulic conductivity, Hydrol. Process., 18, 791-805, 2004.

Vieira, B. C., Fernandes, N. F., and Filho, O. A.: Shallow landslide prediction in the Serra do Mar, São Paulo, Brazil, Nat. Hazards Earth Syst. Sci., 10, 1829-1837, doi:10.5194/nhess-101829-2010, 2010.

Wang, X. and Niu, R.: Landslide intelligent prediction using objectoriented method, Soil Dynam. Earthq. Eng., 30, 1478-1486, 2010.

Wilson, C. J. and Dietrich, W. E.: The contribution of bedrock groundwater to storm runoff and high pore pressure development in hollows. Erosion and Sedimentation in the Pacific Rim Proceedings of Corvallis Symp., August, 1987, IAHS Publ., 165, 49-59, 1987.

Winchester, L. and Szalachman, R.: The urban poor's vulnerability to the impacts of climate change in Latin America and the Caribbean. A policy agenda. Proceedings of Fifth Urban Research Symposium, Marseille, 2009.

Wolle, C. M. and Carvalho, C. S.: Deslizamentos em encostas na Serra do Mar - Brasil, Solos e Rochas, 12, 27-36, 1989.

Wolle, C. M. and Carvalho, C. S.: Taludes Naturais, in:, Solos do Litoral de São Paulo, edited by: Falconi, F. F. and Junior, A. N., ABMS, São Paulo, 180-203, 1994.

Zadeh, L. A.: Fuzzy sets, Inf. Control, 8, 338-353, 1965.

Zaidan, R. T. and Fernandes, N. F.: Zoneamento de suscetibilidade a escorregamentos em encostas aplicado à bacia de drenagem urbana do Córrego da Independência - Juiz de Fora (MG), Rev. Bras. Geomorfol., 10, 57-76, 2009. 